\begin{tabular}{|c|c|c|}
\hline 技 & 術 & 報 \\
\hline
\end{tabular}

\title{
水島製鉄所の建設と操業についで
}

\author{
岩村英 郎**

\section{Construction and Operation of Mizushima Iron Works}

Eiro IWAMURA

\section{1. 緒言}

近時の日本鉄鋼業の飛躍的な国際的地位向上の決定的 な要因となつている，あいつく䉼立地の臨海製鉄所の建 設は, 戦後間もない昭和 26 年に発足した当社千葉製鉄 所がロ火を切つたものといえる。

当時賛否こもごもの世評の中で, 当社初代社長故西山 弥太郎氏の指揮のもとに, 社運をかけて着工されたこの 製鉄所も，昭和 28 年に第 1 溶鉱炉，翌 29 年に平炉お よび第 1 分塊工場が竣工したころ不況に見舞われ，深刻 な資金難のため，しばらくの間は阪神地区社内既設工場 への半成品供給基地の姿にとどまつていた，そのごさま ざまな経緯ののち，第 2 高炉とホットおよびコールド . ストリップミルの完成により，ようやく粗鋼年産 100 万 $\mathbf{t}$ の一貫製鉄所の体跕を整えたのは昭和 33 年春のこと であつた.

このころすでに西山氏は千葉の最終の姿に見通しをつ け, 将来の日本鉄鋼業の発展に対するためには, 当社と して第 2 の新立地に一貫製鉄所を建設する必要のあるこ とを認め, 千葉の拡充と平行してその候補地の探索を開 始したのである.

この候補地の検討は，千葉立地のときと同様に日本全 国にわたつて綿密に進められたが，すでに関東地区に新

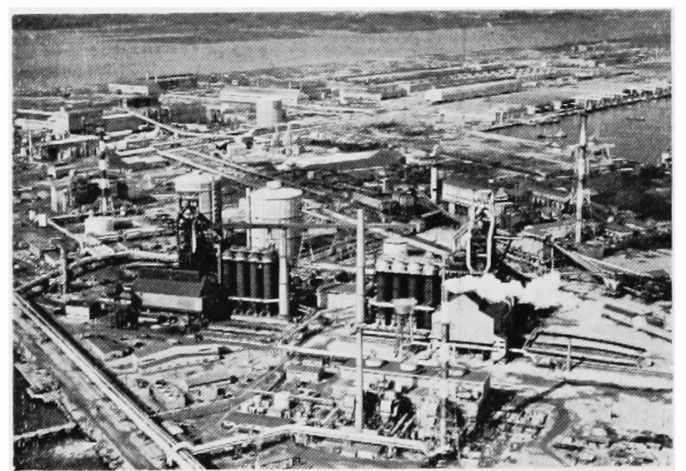

写真 1 水島製鉄所の全景
鋭製鉄所の建設が着々と進行しつつあつたことから，当 然のなりゆきとして，焦点汢大阪以西特に瀬戸内地区に しぼられていつた。 そして数力所の有力な候補の中から 慎重な検討の結果水島地区に決定し, 昭和 36 年岡山県 および倉敖市と誘致協定に調印したのである.

\section{2. 新立地選定の理由}

\section{$2 \cdot 1$ 広大な面積}

千葉製鉄所の建設を計画していた当時は，百万坪の土 地で粗鋼年産 100 万 $\mathrm{t}$ の規模が最終の姿と考えられてい たが，その後あいつぐ設供の增設により工場のスケール も大きくなつたが数年を経ずして敷地の狭险が問題とな るにいたつた。このように技術革新・設備の大型化によ り，製鉄所の経済単位は戦後間もないころの年間 100 万 $\mathrm{t}$ からしだいに膨張して, 昭和 30 年代は $200 〜 300$ 万 $\mathrm{t}$ から 500〜600 万 $\mathrm{t}$ 一と移行していき，40年代の新製鉄 所はいずれも 1000 万 $\mathrm{t}$ 単位が目標とさ机ており, 将来 の発展性を考聋すれば，単一製鉄所として 1500 万ま で生産可能なスペースをとるべきであると考えられる.

この点水島地区惊高梁川河口に位置し, 既成の 106 万 坪の干拓地があり，さらに地先海面は遠浅になつていて 十分に広大な敷地を確保することができる．立地決定の 当時注 600 万 $\mathrm{t}$ の規模を計画したが，逐次計画を拡大し 現在では第 1 期工事として干拓地を含めて 256 万坪の土 地に 1100 万 $\mathrm{t}$ の規模とし，さらに第 2 期工事として 130 万坪以上を埋め立てる権利を留保している.

\section{$2 \cdot 2$ 自然的条件}

水島地区は瀬戸内海に面して気候温和・海上静隐であ つて, 台風・高潮・地震などの天災がほとえどない自然 環境に恵まれている。

地勢は旧高梁川流出土砂により形成された砂州の上に 造成された干拓地および付近の既成陸地と海面埋立地よ りなるが，地盤は地下－12～16m の所から厚さ約 $30 \mathrm{~m}$ におよぶN值 50〜 51 以上の砂碩層が存在して, 製鉄所

* 昭和 44 年 7 月 3 日受付（依頼技術報告）

** 川崎製鉄 (株) 取締役 
のような重量構造物の建設には, 全く理想的な地盤であ る.

また鉄鋼業は用水型産業ともいわれ，多量の工業用水 を必要とするが, 当地は中国地方で最も水量の豊富な高 梁川をひかえており，当製鉄所が最終的に必要とする淡 水30万 $\mathrm{t} /$ day は十分確保できる。

\section{3 经済的条件}

第 1 期工事の工場敷地として予定した海面は，水深最 高- $3 \cdot 5 \mathrm{~m}$ 程度の遠浅になつており, 埋立土量は少なく てすみ，既成陸地および埋立地平均して坪あたり 4500 円くらいの安価な地価となる。また付近海面の浚渫土の 大半はきわめて良質の砂䃯からなり，余剩浚渫土を各設 備の基礎コンクリートの骨材として利用することができ た.

さらに当地は瀬戸内海の中央に位置し，交通は海上 陸上とも至便で，特に海上輸送を主体とする臨海製鉄所 としては，瀬戸内海本航路から水島港に通ずる水深-16 $\mathrm{m}$ の水島航路およびー16〜 $17 \mathrm{~m}$ の泊地が整備されている ため, 大型船舶が自由に入港することができ, 海上運賃 の軽减という恩恵を享受することができる.

このほか, 水島地区は新興の臨海工業地帯として最近 脚光を浴びて登場したばかりで, 後背地に未開発の豊富 な労㗢力が温存されているので，当製鉄所最終計画まで の労㗢力の確保は可能である.

さらに当地法阪神工業地带に隣接し, 瀬戸内海沿岸に は自動車・造船など各種重工業が発達しており,これら の大きな需要に対し適時に応ずることができる.

以上のような諸利点から見て, 当社は東の千葉製鉄所 に対応した西の拠点として，水島地区を第 2 の製鉄所の 用地に選定したわけである。

\section{3. 工場レイアゥト}

誘致協定に調印した時の地形としては図 1 に示すよう に, 東は水島航路・南は上水島から $800 \mathrm{~m}$ 幅の玉島航路

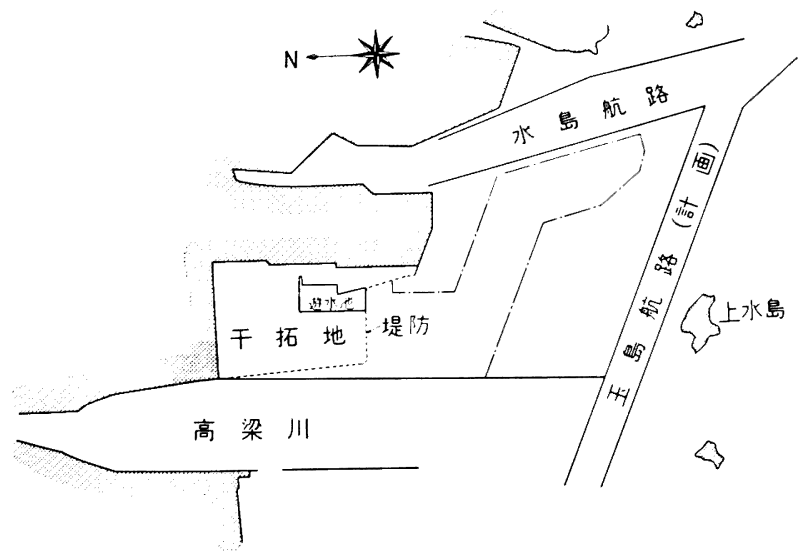

図1 水島製鉄所地形図
の計画路線そして西は高梁川の対岸と平行した線の 3 本 の線によつて囲まれた奇妙な形で，これが製鉄所の地形 を決定する上での大前提であつた.

さて第 1 期工事として粗鋼年産 1100 万 $\mathrm{t}$ もの膨大な 規模をむつ製鉄所のレイアウトを考察するにあたつて， 各設備の合理的な配置が必要不可欠の要件であるが，こ のさい最も留意すべきことは原料・半成品抢よび製品の 輸送問題である。

原料の搬入 ・半成品および製品の搬出はほとんど海上 輸送に頼ることになるので, 海岸線の長い地形にするこ とが望ましい，また場内輸送については，高炉原料のほ かは注とえどが重量物の運搬で，大量にしかも頻繁に行 なう必要があるので，軌道輸送に頼らざるを得ない。こ の場合折返しや線路の平面交叉があると, 列車の一且停 止による輸送時間の延長とか，線路の曲線部の增加によ る走行抵抗の増大など多くの欠陷が生じ，また相対的に 輸送距朔が延長することになる．さらに折返し方式を採 用したレイアウトでは, 当初の計画時に将来の設備配置 がある程度規制されて弾力性を欠くことになり，将来の 技術革新による設備の変更などに対処することが困難と なろう.したがつて材料・半成品が一方向に淀みなく円 滑に流れるような，また最終計画までを考虑したレイア ウトについて種々検討した。

このようにして最終的に決定した地形およびエ場レイ アウトが瓦 2 に示すものである・

すなわち全用地を 2 分割し，さしあたつての第 1 期工 事用地は 256 万坪の長靴型の地形とし, 残りは将来用地 として埋立権を確保した。

鉱石・石炭岸壁は，15万 $\mathrm{t}$ 級以上の大型専用船の出入 を容易にするため，水島航路（現在水深－16m）に通ず る切込港湾を設けることにより，十分に長い延長線をも つ鉱石岸壁を確保し，他方石炭岸壁は水島航路沿いに設 置することにした。ただし現在は岸壁長さになお余裕が あるので，鉱石岸壁を鉱石・石炭のコモン・バースとし て使用しており，その水深はー $17 \mathrm{~m} て ゙$ 第 3 高 炉建設時にはー $18 \mathrm{~m}$ の岸壁を増設することに している.これら岸壁の背後にこれと平行し てそれぞれ鉱石・石炭ヤードを設け，これら ヤードからほぼ同じ距漓の所に高炉群を配置 することにした。

高炉は 4 基からなるがその高炉群の配置に ついては，溶銑線に対して平行配置か傾斜配 置かの決定に迷つたが，4基もの超大型高炉 を一列に配置するには場所的な制約があるほ か，溶銑線の総延長が增大するため，折哀案 として図 3 に示すように，2 基の高炉をペア としたツイン型傾斜配置にすることに決定し た。これにより溶銑車の運行に際して，交錯 折返しを最小限にしうると期待される。 


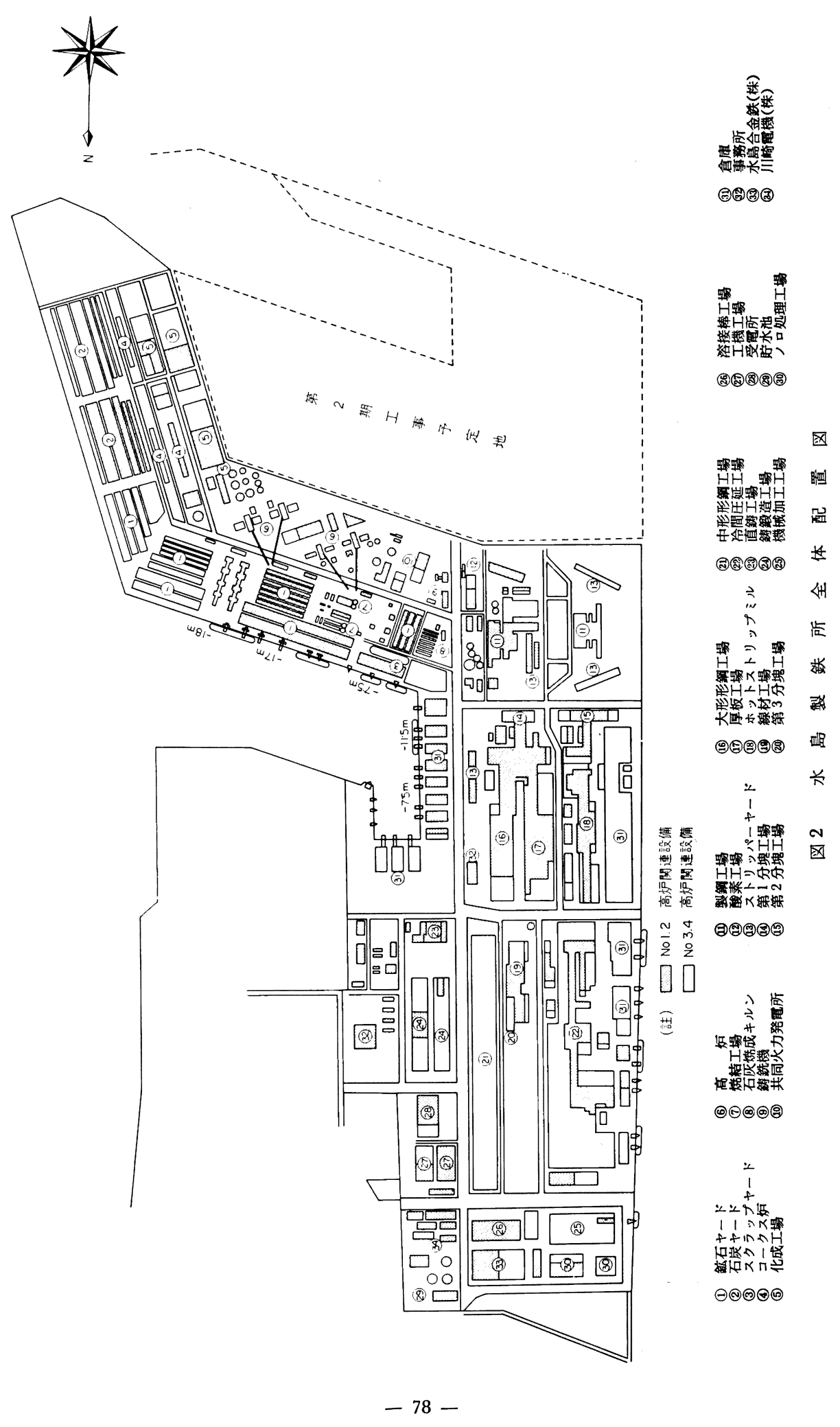




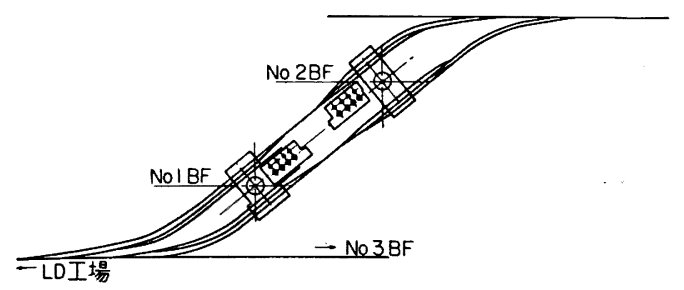

図 3 No 1，2 高炉配置図

このようにして製銑地区は半島部に収容することがで きたが，製鉄所地形が細長い形状であるため，敷地内を 南北に貫通するグリーン・ベルトと称する幹線道路を設 け，その中央部に高圧送電線・給排水本管その他ユティ リティー関係の主配管類を走らせた．そしてこのグリー ン・ベルトより西側の長方形の地形内に製鋼・圧延の主 要設備を配置した.すなわち高炉から出る溶銑をほとん そ消費する転炬工場は, 当然高炉群から最も近い南部地 区におき，ここを出発点として各種圧延設備を工程順に 北に向かつて配列してある.

粗鋼 1100 万 $\mathrm{t}$ の時点では，製品は年間約 900 万 $\mathrm{t}$ に も達し，しかもその積出しはほとんど海上輸送になるの で, その船積み場は 2 力所に分け, 条鋼・棒鋼類は切込 港湾の奥に設けた製品岸壁, 厚板・薄板は高梁川沿岸の 岸壁を使用することにした。

なお工場敷地の北部地区は，一貫工程とは直接関係の ない鋳鍛鋼設備や，合金鉄製造その他 2 次 3 次製品加工 の関連企業などの用地として確保した。

このように長靴型の細長い地形の中に，その先端から 付根に向かつて物資を流す方式は，建設計画の初期の段 階ではたしかに必要以上に長い輸送距離となつて不利で あるが，建設の進行につれて次第にその合理的な配置の 強味を発揮していくことになろう。

\section{4. 一貫体制確立までの建設過程}

話は前後するが水島地区を新立地に選定した当時は， ちようど千葉製鉄所の増強期にあたり，なお当分の間こ こに一貫体制を布く必要がなく，また資金的余裕も少な かつたので，地先海面の埋立は経済的なテンポで進めら れていた。

ところで当社の特殊事情として，当社製品のワイヤロ 一プ・溶接棒の素材ロッドは途中工程を他社に依存して おり，また棒鋼も老朽設備で製造されていて，いずれも 製造コストが高く採算割れとなつていた。この問題を解 決するために，既成干拓地内に新鋭の小形線材工場がま ず建設され，その完成をみたのは昭和 40 年 10 月のこ とであつた.ついで千葉製鉄所の増強も最終段階となり 分塊々ル能力の不足が予想されるにいたつたので, 昭和 41 年 8 月第 1 分塊工場が予定され，その次にはじめて一 貫体制となるのであるが，この場合も当社の压延設備の
中で最も能力不足の厚板設供が，水島で新設すべき压延 設備の第 1 候補とされた.

このように水島は千葉その他社内各工場の補完的な性 格を持たされた結果, ストリップ・ミルの建設が後廻し となり，大型高炉 2 基を持つ現在でもなおしばらくの間 他工場への半成品供給基地の姿が強く残ることになる.

さて干葉製鉄所は昭和 40 年 4 月第 5 高炉の完成により 粗鋼年産 600 万 $\mathrm{t}$ の規模に達しこれ以上の拡張の余地は 全くなくなり，他方水島の地先海面の埋立も予定通り進 行中であつたので, 水島地区の一貫化がはじめて実施の 段階にはいつた。しかしながら一貫体制の着工当時は， 不況により資金事情が窮迫し，また高炉 1 セット粗鋼 200 万 $\mathbf{t}$ という規模を一気に完工することは, 当社にと つてステップとして大きすぎるとの判断から，需給バラ ンス上まず 100 万 $\mathrm{t}$ プラントを建設することにした.す なわち高炉本体・転炉自体は 200 万 $\mathrm{t}$ のユニットとする が，周辺設備は当初 100 万 $\mathrm{t}$ 生産に必要なもののみにと ぞめて，建設初期の 所要資金を極力圧 縮することとし た・たとえば製銑関係については，当時の原料事情を勘 案して焼結用粉鉱石の購入が比較的容易であつたので， 思いきつて整粒設備を後廻しにしてほとえど全量を焼結 鉱装入とし，一部購入ペレットおよび山元整粒鉱に頼る ことにした。 また熱風师も 4 基のうち 3 基，180 度対向 型の鋳床 2 面も当初は 1 面のみとした. 製鋼関係ではス クラップは全量還元屑のみを使用することとし, 購入佰 荷揚げ用の岸壁・アンローダーおよびこれに見合うスク ラップ・ヤードを一切カットした.

このように非常に窮屈な姿で発足したが, 着工直後幸 いにして市況が大幅に好転し，すぐ追いかけて 200 万 プラントにするための補完設備に着工して, 第 1 高炉火 入れ後 $6 \sim 9$ 力月には本来の姿にすることができた. そ のご逐次設備の拡充・新設をつゔけ, 本年 1 月第 2 高炉 の火入れ，4月第 3 転炉の完成により粗鋼年産 450 万 $\mathbf{t}$ の体制にはいり，ストリップ・ミルもコールドは本年10 月ホットは明年 1 月完成の運びとなり，ようやく新鋭製 鉄所の形体を整えることになる.

以下工程順に各設備の建設状況・設備内容および操業 状況につき概説する.

\section{5. 製 銑 設 備}

\section{1 出銑能力}

4 基の大型高炉はいずれも建設当時の最新技術の粋を 集めて, 製造コストの低减, 生産性の向上を計る. その出 銑比は $2 \cdot 1 \sim 2 \cdot 2 \mathrm{t} / \mathrm{m}^{3}$. day は可能であるから, 表 1 亿示 すように出銑量は合計 $26000 \mathrm{t} / \mathrm{day}$ となり, 年間約 950 万 $\mathrm{t}$ の生産が見込まれる。

\section{$5 \cdot 2$ 鉄鉱石}

高炉装入鉱石の鉱石比を 1.6 とすれば, 高炉 4 基時の 装入鉱石量は約 1520 万 $\mathrm{t} /$ year となるが，うち処理鉱 
表 1 高炉の生産能力

\begin{tabular}{l|c|c|c}
\hline \hline 高炉名 & 内容積 $\left(\mathrm{cm}^{3}\right)$ & 出跣量 $(\mathrm{t} / \mathrm{d})$ & 完成年月 \\
\hline No 1 & 2150 & 4600 & S 42-4 \\
No 2 & 2857 & 6300 & S 44-1 \\
No 3 & 約 3300 & 7300 & S 45-9(予定) \\
No 4 & 約 3500 & 7800 & S 47-3(予定) \\
\hline 合計 & - & 26000 & \\
\hline
\end{tabular}

表 2 焼 結 機 の 概 要

\begin{tabular}{|c|c|c|c|}
\hline 焼結機名 & $\begin{array}{c}\text { 火格子面積 } \\
\left(\mathrm{m}^{2}\right)\end{array}$ & $\begin{array}{l}\text { 能 力 } \\
(\mathrm{t} / \text { day })\end{array}$ & 完成年月 \\
\hline $\begin{array}{l}\text { 第 } 1 \text { 焼結 } \\
\text { 第 } 2 \text { 焼結 } \\
\text { 第 } 3 \text { 焼結 } \\
\text { 第 } 4 \text { 焼結 }\end{array}$ & $\begin{array}{l}183 \\
250 \\
\text { 約 } 300 \\
\text { 約 } 300\end{array}$ & $\begin{array}{l}5600 \\
7700 \\
8800 \\
8800\end{array}$ & $\begin{array}{l}\text { S } 42-3 \\
\text { S 44-1 } \\
\text { S 45-9(而定) } \\
\text { S 47-3 (争定) }\end{array}$ \\
\hline 計 & - & 30900 & \\
\hline
\end{tabular}

は 70〜80\% の焼結鉱と若干量の賱入ペレットとすれば 㮱結用粉鉱は約 960 万 $\mathrm{t}$ となる. そして塊精鉱の装入量 は約 380 万 $\mathrm{t}$ となるが，整粒工程における粉発生率を40 \%とすれば，切込鉱 : 635 万 t $(=380 \div 0.6)$

$$
\text { 発生粉 : } 255 \text { 万 } \mathrm{t}(=635 \times 0.4)
$$

したがつて年間所要鉄鉱石は塊鉱石 635 万 $\mathrm{t}$, 粉鉱石は 705 万 $\mathrm{t}$ となり，合計 1340 万 $\mathrm{t}$ と計上される.

なお鉱石の整粒設備は能力 $1000 \mathrm{t} / \mathrm{hr}$ のもの 4 系列 からなり，4次破砕まで行なつて整粒鉱の粒度を 9 25 mmにおさめる.

所要の焼結鉱を確保するため, 表 2 に示すような焼結 設備を逐次設置する計画である. いずれもルルギー式の 大型機で, 合計年間的 1130 万 $\mathrm{t}$ となり, 所定の焼結比 を確保することができる。

\section{$5 \cdot 3$ 鉱石ヤード}

鉱石ヤードの全体配置罒は図 4 に示すとおりである. 鉱石岸壁から荷揚げ後，粗鉱ヤードに全量いつたん銘柄 別に仮置きし，切込鉱は破砕篩分設備を経て整粒鉱と篩 分粉鉱に分けられる. 前者は精鉱ヤードに銘柄別に貯蔵
表 3 鉱石ヤード面積および貯鉱量

\begin{tabular}{c|r|c|c}
\hline \hline ヤード名称 & 面数 & 総面積 $\left(\mathrm{m}^{2}\right)$ & 貯鉱能力 $(1000 \mathrm{t})$ \\
\hline 粗鉱ヤード & 6 & 124300 & 1178 \\
精鉱ヤート & 5 & 26300 & 696 \\
オフ・ヘッド & 10 & 72000 & 600 \\
\hline 合 計 & 24 & 222600 & 2474 \\
\hline
\end{tabular}

しておき必要に応じてオアベッドに，後者および粉鉱は 直接オア・ベッドに送られ，ともにそれぞれのベッドで 十分ブレンドして後，貯鉱槽または焼結工場へ搬送され る.この間の輸送はすべて遠隔操作によるベルト・コン ベヤ方式をとつている。

さて 1 日平均輸入鉱石量は約 $36700 \mathrm{t}$ となるが，これ に対し鉱石ヤード面積および貯鉱能力は表 3 のようにな り，65日分以上の貯鉱が可能なので，貯鉱能力は十分と 考えられる.

鉄鈗石以外の鉄マンガン鉱・石灰石その他の雑原料は 鉱石岸壁の $500 \mathrm{t}$ アンローダーで水揚げし，雑原料ヤー ドに貯蔵する．このヤードは焼結工場の稼動状況が直接 高炉操業に影響するのを防ぐため, 適量の焼結鉱の貯蔵 場としても使用されている.

\section{4 石宸およびコークス}

出銑量 $26000 \mathrm{t} / \mathrm{day}$ に対し，コークス比を 470 480 $\mathrm{kg} / \mathrm{t}$ とすれば, 塊コークス必要量は約 $12400 \mathrm{t} /$ day と なる。これに対するコークス炉は表4のように計画して いる、いずれもカール・スティル社の設計によるもので 第 1 . 2 コークス炬梳高 $6550 \mathrm{~mm}$, 第 $3 \cdot 4$ は 6800 $\mathrm{mm}$ の国内随一の大型炉である. 表 4 から判明するよう に, 高炉のコークス所要量ばかりでなく, 焼結用粉コー クスもほとんど自給することができる.

原料炭は現在鉱石岸壁・将来は石炭岸壁から水揚げし てのち, 石炭ヤードに銘柄別に貯蔵し, ついで破砕篩分 設備を経て配合ヤードに送り，ここで鉄鉱石と同じよう にヤード・ブレンディングを行なうのが特色で，その後 コークス炉に払い出される.これらの石炭ヤードは表 5

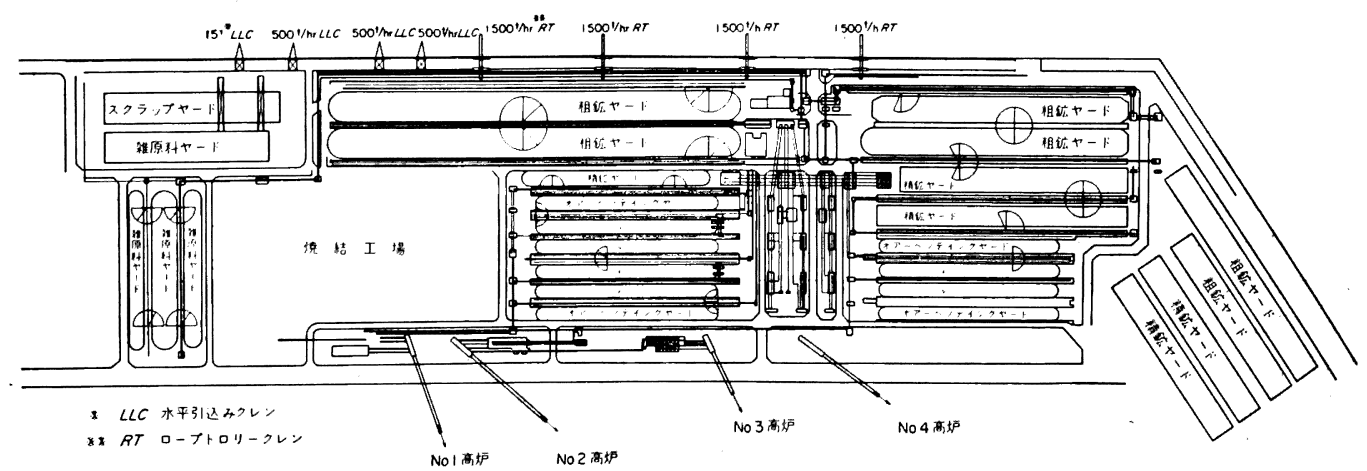

図 4 鉱石 $ヤ$ 一 全体配置図 
表 4 コ ク ス 炉 概 要

\begin{tabular}{|c|c|c|c|c|c|c|}
\hline 帄 & 門 数 & 1 門あたり寸法 ( $\mathrm{mm})$ & $\begin{array}{c}\text { 生産能力 }(\mathrm{t} / \mathrm{d}) \\
\text { (高炉前換算) }\end{array}$ & 完 & 成 年 & 月 \\
\hline No 1コークス炉 & $39 \times 2$ & $420 \times 15950 \times 6550$ & 2290 & $\begin{array}{l}\text { A 炬団 } \\
\text { B " }\end{array}$ & $\begin{array}{l}\text { S } 42 . \\
\text { S } 42\end{array}$ & $\begin{array}{r}3 \\
12\end{array}$ \\
\hline No 2 & $43 \times 2$ & " & 2530 & $\begin{array}{l}A " 1 \\
B "\end{array}$ & $\begin{array}{l}\text { S } 43 . \\
\text { S } 44 .\end{array}$ & 12 \\
\hline No 3 & $43 \times 2$ & $420 \times 15950 \times 6800$ & 2640 & $\begin{array}{l}A " 1 \\
B "\end{array}$ & $\begin{array}{l}\text { S } 45 . \\
\text { S } 45 .\end{array}$ & $\begin{array}{l}1 \text { (予定) } \\
9 \text { (" })\end{array}$ \\
\hline No 4 & $43 \times 2$ & " & 2640 & $\begin{array}{l}A " 1 \\
B "\end{array}$ & $\begin{array}{l}\text { S } 46 . \\
\text { S } 47 .\end{array}$ & $\begin{array}{l}3(" \prime) \\
3(" \prime)\end{array}$ \\
\hline No 5 & $43 \times 2$ & " & 2640 & $\begin{array}{l}\mathrm{A} " 1 \\
\mathrm{~B} "\end{array}$ & $\begin{array}{l}\text { S } 47 . \\
\text { S } 48 .\end{array}$ & $\begin{array}{l}9(" \prime) \\
3(")\end{array}$ \\
\hline 計 & - & - & 12740 & & & \\
\hline
\end{tabular}

表 5 石 炭 $ヤ-ト ゙$ 概 要

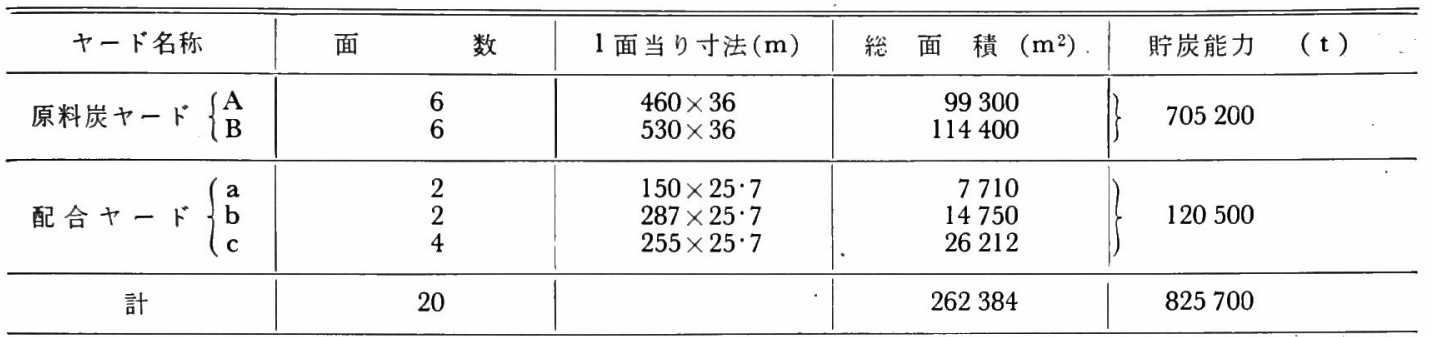

表 6 第 $1 \cdot 2$ 高炉の主要仕様

\begin{tabular}{|c|c|c|c|}
\hline & 第 1 高 叔 & 第 2 高 炉 & \\
\hline 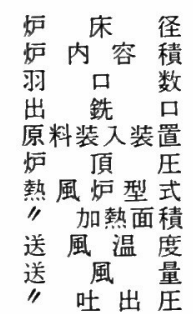 & 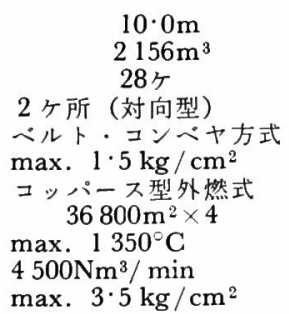 & 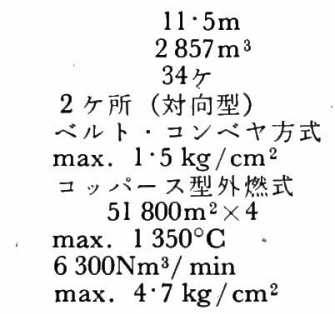 & \\
\hline
\end{tabular}

に示すとおりであるが，高炉前換算の塊コークス生産量 が 12740 t/day であるから，所要原料は約_19600t/day となつて, 貯炭能力は約 42 日分となり若干不足気味で あるが, 必要ならば地先海面の埋立てを行なつてヤード の増設を行なうこともできる.このほかコークス炉の炉 況変動に対処するため, 約 5 万 $\mathrm{t}$ 分のコークス置場を確 保してある.タールその他副産物の精製のための若干の 化成設備屯設置されている，なおコークス炉関係は川鉄 化学(株)に所属している.

\section{5 高炉およびその操業状況}

現在 2 基の高炉が稼動中で, その主要仕様を表 6 に示 す,

第 1 高炉は千葉第5 高炉をほぼ同じ設備であるが，若

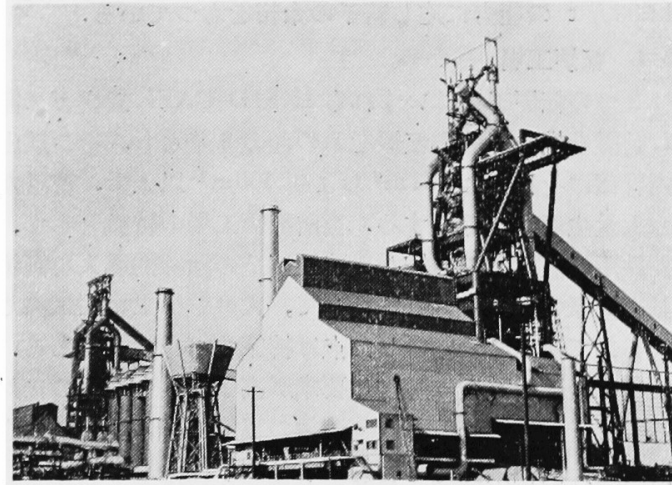

写真 2 第 1 . 第 2 溶鉱炉（右側第 2 溶鉱炉） 
干の改善を加えてある．たとえば高压操業設備は千葉の ベル方式をやめてパルブ・シール方式とし，熱風炉は高 さをより高くして熱効率の向上・大容量化をはかつてあ る.また溶銑の輸送は $250 \mathrm{t}$ 混銑車を採用し, 溶滓はド ライ・ピットを設けて, 従来の溶㳯鍋輸送に要する設供 費を削減した。

第 2 高炉は本年 1 月13日火入れを行なつたばかりで, 第 1 高炉の経験を生かすとともに，積極的に新技術を採 用して設計・製作された最新鋭の高炉である. 第 1 高炉 とのおもな相違点はつぎのとおりである.

（1）内容積 $2857 \mathrm{~m}^{3}$, 炉床径 $11.5 \mathrm{~m}$ と大型化し, これにともなつて付带設備も大型化したこと.

（2）千葉第 5 ・水島第 1 高炉で採用した 6 本の鋼管 柱による炬体支持方式をやめ，鋼管柱を 4 本として炬頂 部の荷重を受け，シャフト部は 4 本のシャフト・カラム で支持する方式としたこと。

（3）朝顔および灯腹部にステーブ冷却方式を採用し シャフト部は全数密閉型冷却函で泠却することにしたこ と.

（4） 高圧操業設備のうち・ガスコンプレッサーによ る二次均圧をやめ，荒ガス均圧方式としたこと．

なお図 5 に第 2 高炉本体の断面図を示してある.

これら 2 基の高炉はいずれもきわめて順調な操業を続 けており, その火入れ以来の操業成績は表 7 および表 8 に示すとおりである，

なお両高炉とも熱風炉は業界通例の 3 本に対し 4 本を 採用しているが，これは4本のほうが熱風炉の熱効率が 向上して, 本数増による設備費の増加を短期間で回収し うることが判明したためであつて，今後ともこの方式を 採用していく考えである, なお両高炉とも高炉作業デー タの収集と, 怩況制御のためのプロセス・コンピュータ 一を採用してある。

\section{6. 製 鋼 設 備}

製鋼工場は表 9 に示すように，2つの転炉工場と電気 炉工場とからなつていて，第 1 期工事完成時に は粗鋼 1200 万 の能力に達し若干の余裕をもつている.

\section{6 . 1 転炉工場}

2 つの転炉工場はいずれも IRSID-CAFL 式排ガス回 収装置を備えた大型転师をおのおの 3 基もち，その鉄皮 内容積はそれぞれ $331 \mathrm{~m}^{3}$ および $400 \mathrm{~m}^{3}$ 以上で, 普通鋼 の大量生産を目標とする. 当所転炉工場の特徵と乙て, 製鉄所建設計画の当初から連続鋳造の積極的導入を画策 し, 従来の造塊設備と併行して, 大型転炉工場に本邦で はじめて連鋳機を設置した点は特筆すべきことである. このほか近時品質に対する要求が高まりつつあるのに対 処して, 溶銑の脱硫装置・溶鋼の真空脱ガス装置などを 備えて, 高級鋼生産を容易にするよう配慮されている。

第 1 転炉工場は本年 4 月第 3 転炉の増設により，3 基

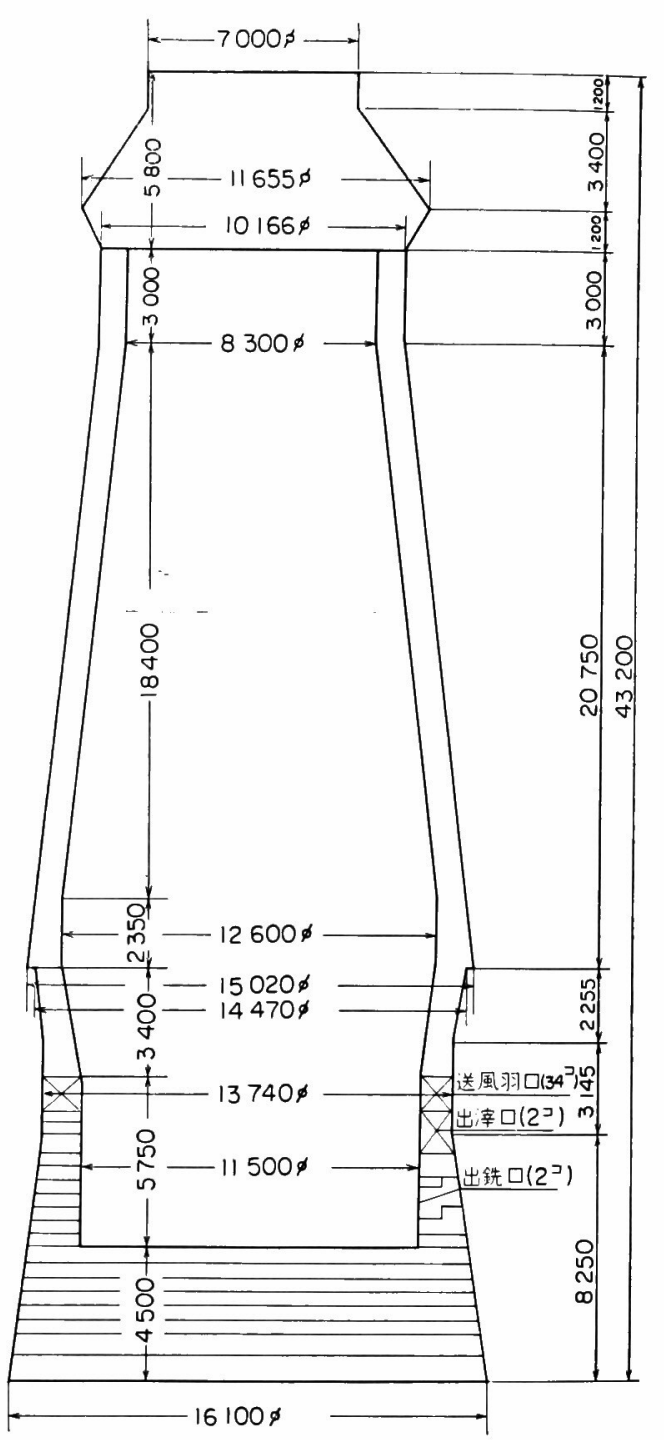

因 5 第 2 高炉本体断面図

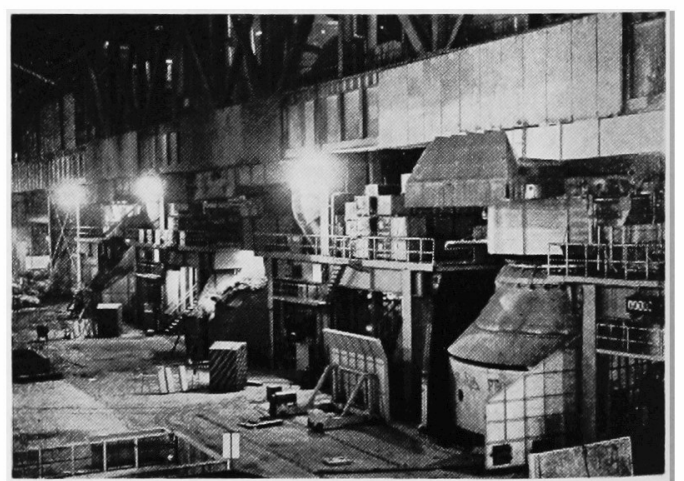

写真 3 第 1 転炉工場 
表 7 第 1 高师 の操業成 績

\begin{tabular}{|c|c|c|c|c|c|c|c|}
\hline 月 & $\begin{array}{l}\text { 出 銑 量 } \\
\text { (t/day) }\end{array}$ & $\begin{array}{r}\text { 出 銑 比 } \\
\left(\mathrm{t} / \mathrm{m}^{3}\right)\end{array}$ & $\begin{array}{c}\text { בークス比 } \\
(\mathrm{kg} / \mathrm{t})\end{array}$ & $\begin{array}{l}\text { (焼結+ペンッ } \\
\text { ト比) }(\%)\end{array}$ & $\begin{array}{c}\begin{array}{c}\text { 送風温度 } \\
\left({ }^{\circ} \mathrm{C}\right)\end{array} \\
\end{array}$ & $\mathrm{O}_{2}$ 富化率 & 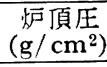 \\
\hline $\mathrm{S} 42 / 4$ & $*\left(\begin{array}{ll}1 & 250)\end{array}\right.$ & $0 \cdot 58$ & 662 & $88 \cdot 4$ & 724 & - & $91 \cdot 8$ \\
\hline & 2238 & $1 \cdot 04$ & 550 & $92 \cdot 9$ & 911 & - & $122 \cdot 0$ \\
\hline 6 & 2916 & $1 \cdot 35$ & 518 & $90 \cdot 3$ & 1065 & - & $142 \cdot 0$ \\
\hline 7 & 3019 & $1 \cdot 40$ & 510 & $87 \cdot 3$ & 973 & - & $143 \cdot 0$ \\
\hline 8 & 3327 & $1 \cdot 54$ & 506 & $86 \cdot 7$ & 945 & - & $140 \cdot 5$ \\
\hline 9 & 3713 & $1 \cdot 72$ & 492 & $83 \cdot 2$ & 976 & - & $141 \cdot 7$ \\
\hline 10 & 3761 & $1 \cdot 74$ & 483 & $80 \cdot 2$ & 990 & - & $138 \cdot 1$ \\
\hline 11 & 3583 & $1 \cdot 66$ & 483 & $82 \cdot 2$ & 988 & $0.4 \%$ & $137 \cdot 3$ \\
\hline 12 & 4043 & $1 \cdot 88$ & 474 & $81 \cdot 1$ & 1004 & $1 \cdot 5$ & $166^{\circ} 0$ \\
\hline $43 / 1$ & 4237 & $1 \cdot 97$ & 468 & $79 \cdot 1$ & 1054 & $1 \cdot 2$ & $267 \cdot 2$ \\
\hline 2 & 4587 & $2 \cdot 13$ & 475 & $73 \cdot 3$ & 1064 & $1 \cdot 4$ & $599 \cdot 0$ \\
\hline 3 & 4425 & $2 \cdot 05$ & 482 & $70 \cdot 4$ & 1053 & $1 \cdot 3$ & $649 \cdot 0$ \\
\hline 4 & 4370 & $2 \cdot 03$ & 478 & $71 \cdot 3$ & 1033 & $1 \cdot 3$ & 801 \\
\hline 5 & 4669 & $2 \cdot 17$ & 477 & $70 \cdot 3$ & 1049 & $1 \cdot 4$ & 1088 \\
\hline 6 & 4747 & $2 \cdot 20$ & 476 & $67 \cdot 1$ & 1062 & $1 \cdot 2$ & 1192 \\
\hline 7 & 4311 & $2 \cdot 00$ & 488 & $73 \cdot 9$ & 1084 & $1 \cdot 5$ & 979 \\
\hline 8 & 4720 & $2 \cdot 19$ & 482 & $70 \cdot 9$ & 1085 & $1 \cdot 4$ & 1160 \\
\hline 9 & 4210 & $1 \cdot 95$ & 494 & $67 \cdot 2$ & 1057 & $1 \cdot 5$ & 1043 \\
\hline 10 & 4920 & $2 \cdot 28$ & 485 & $67 \cdot 3$ & 1095 & $1 \cdot 5$ & 1256 \\
\hline 11 & 4669 & $2 \cdot 17$ & 489 & $71 \cdot 6$ & 1083 & $1 \cdot 4$ & 1098 \\
\hline 12 & 4706 & $2 \cdot 18$ & 490 & $70 \cdot 5$ & 1078 & $1 \cdot 6$ & 1213 \\
\hline S 44/1 & 4688 & $2 \cdot 17$ & 488 & $70 \cdot 1$ & 1073 & $1 \cdot 7$ & 1260 \\
\hline 2 & 4296 & $1 \cdot 99$ & 494 & $72 \cdot 2$ & 1045 & $2 \cdot 0$ & 1165 \\
\hline 3 & 4434 & $2 \cdot 06$ & 491 & $73 \cdot 0$ & 1060 & $1 \cdot 4$ & 1210 \\
\hline 4 & 4273 & $1 \cdot 98$ & 478 & $76 \cdot 4$ & 1069 & $1 \cdot 2$ & 1104 \\
\hline 5 & 4386 & $2 \cdot 04$ & 499 & $70 \cdot 0$ & 1036 & $1 \cdot 2$ & 1055 \\
\hline
\end{tabular}

* 実稼動日数あたりの出銑トン数

表 8 第 2 高炉 の操業成績

\begin{tabular}{|c|c|c|c|c|c|c|c|}
\hline 年 & $\begin{array}{l}\text { 出 銑 量 } \\
(\mathrm{t} / \text { day) }\end{array}$ & $\begin{array}{r}\text { 出 銑 比 } \\
\left(\mathrm{t} / \mathrm{m}^{3}\right)\end{array}$ & $\begin{array}{c}\text { コークス比 } \\
(\mathrm{kg} / \mathrm{t})\end{array}$ & 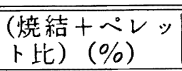 & $\begin{array}{c}\text { 送風温度 } \\
\left({ }^{\circ} \mathrm{C}\right)\end{array}$ & $\mathrm{O}_{2}$ 富化率 & $\begin{array}{l}\begin{array}{l}\text { 忓頂压 } \\
\left(\mathrm{g} / \mathrm{cm}^{2}\right)\end{array} \\
\end{array}$ \\
\hline $\begin{array}{r}\mathrm{S} 44 / 1 \\
2 \\
3 \\
4 \\
5\end{array}$ & $\begin{array}{c}*(2569) \\
3684 \\
4026 \\
4386 \\
5187\end{array}$ & $\begin{array}{l}0 \cdot 90 \\
1 \cdot 29 \\
1 \cdot 41 \\
1 \cdot 54 \\
1 \cdot 82\end{array}$ & $\begin{array}{l}588 \\
532 \\
506 \\
486 \\
496\end{array}$ & $\begin{array}{l}59 \cdot 1 \\
64 \cdot 2 \\
67 \cdot 8 \\
75 \cdot 4 \\
70 \cdot 1\end{array}$ & $\begin{array}{r}884 \\
985 \\
1003 \\
1008 \\
1025\end{array}$ & $\begin{array}{l}- \\
- \\
-\end{array}$ & $\begin{array}{r}154 \\
296 \\
514 \\
674 \\
1013\end{array}$ \\
\hline
\end{tabular}

* 実稼動日数あたりのトン数

整備 2 基稼動の体制が整つたがここには 1 回の処理量 $200 \mathrm{t}$ の $\mathrm{R}-\mathrm{H}$ 式脱ガス装置および世界最大級の連鋳機 を設置しており溶銑脱硫装置も設置中である. 本年さら にスラブ用連鋳機の建設に着手し，将来 3 基の連鋳機を もつことになり，主として厚板・大中形および棒鋼線材 ミル向けの素材を供給する工場となる。図 6 は完成した 第 1 転炉工場のレイアウトを示すが, 現在第 2 高炉の生 産増に応じて次第に生産を高めている。

他方第 3 高炉の完成と同時に稼動寸る予定の第 2 転炉 工場は，高炉の炉容拡大に応じて内容積 $400 \mathrm{~m}^{3}$ 以上の 大型転师を備え，主としてストリップミル向け鋼塊の生 痤を計画している. 本工場についても, 必要に応じて連 鋳その他最新技術の粋をあつめる考えである。

\section{2 龟気炬工場}

当社兵庫工場は鋳鍛鋼の専門工場であるが, 各設備と も老朽かつ小型で製造コストが高く, 早急に設備更新が
必要であるので，工場全体の水島への移設が決定され た. 本工場はその一環となるものであり, 現在この電気 炉工場の造塊ヤード内に, 明年 3 月末完成予定でASEA -SKF 方式のレードル・フォーネスを建設中であり, さ らに $30 \mathrm{t}$ および $100 \mathrm{t}$ 電気炉を設置して, 鋳鍛鋼用素 材および特殊鋼の製造を子定している.

レードル・ファーネスは 1 回あたり $100 \mathrm{t}$ の溶鋼を処 理することができ, 溶鋼の真空脱ガス・温度および成分 調整を行なうものである.したがつて溶鋼はプレン・カ 一ボンですみ安価な転炉の溶鋼を使用して鍛鋼品に適応 する清浄な高級鋼を製造することができる.

\section{$6 \cdot 3$ 連続鋳造設備}

近時連続鋳造法の発達はめざましく, 日本においても 最近ぞくぞくと採用され始めたが，当社も水島製鉄所の 開設の当初から, 全面的な連続踌造法の導入の可能性に ついて種々調査研究を続けてきた.しかしながら現時点 
表 9 製 鋼 工 場 総 括

\begin{tabular}{|c|c|c|c|c|c|}
\hline 工 場 & 炉の基数 & $\begin{array}{c}\text { 生産能力 } \\
\text { (1000t/year) }\end{array}$ & 製造鋼種 & & 完 成 年 月 \\
\hline 第 1 転炬工場 & $200 \mathrm{t} \times 3$ 基 & 5500 & 普通釗 & $\left\{\begin{array}{l}2 \text { 基 } \\
1 \text { 基 }\end{array}\right.$ & $\begin{array}{l}\text { S 42-4 } \\
\text { S 44-4 }\end{array}$ \\
\hline 第 2 転炬工場 & $250 \mathrm{t} \times 3$ 基 & 6500 & 普通釗 & 鋼 $\left\{\begin{array}{l}2 \text { 基 } \\
1 \text { 基 }\end{array}\right.$ & $\begin{array}{l}\text { S 45-9 (予定) } \\
\text { S 47-3 (.." })\end{array}$ \\
\hline 電気炉工場 & $30 \mathrm{t} \times 1$ 基 $100 \mathrm{t} \times 1$ 基 & 300 & 鋳鉎鋼・特殊釗 & $\begin{cases}30 \mathrm{t} \\
100 \mathrm{t}\end{cases}$ & $\begin{array}{l}\text { S 46-9 (予定) } \\
\text { S 47-12 (" })\end{array}$ \\
\hline 計 & - & 12300 & & & \\
\hline
\end{tabular}

表 10 連 鋳 機 の 概 要

\begin{tabular}{|c|c|c|c|c|c|c|}
\hline 機 & 号 & 片 & 設 置 場 所 & ヒートサイズ & 力 & 鋳片向け先 \\
\hline $\begin{array}{l}\text { No } 1 \\
\text { No } 2 \\
\text { No } 3\end{array}$ & $\begin{array}{l}\mathrm{C} \text { C } \\
11 \\
11\end{array}$ & $\begin{array}{l}\text { ブルーム } \\
\text { スララブ } \\
\text { ブルーム }\end{array}$ & $\begin{array}{l}\text { No } 1 \\
\text { L D工場 }\end{array}$ & $\begin{array}{l}200 \mathrm{t} \\
200 \\
200\end{array}$ & $\begin{array}{l}1000 \text { 千 } \mathrm{t} / \text { 年 } \\
1000 \\
1200\end{array}$ & $\begin{array}{l}\text { 中形・棒鋼・鋼片 } \\
\text { ストリップ } \\
\text { 中形・棒鋼 }\end{array}$ \\
\hline No 4 & " & スラブ & No 2 L D工場 & $250 \mathrm{t}$ & 1500 & ストリップミル・厚板 \\
\hline 計 & & - & - & - & 4700 & - \\
\hline
\end{tabular}

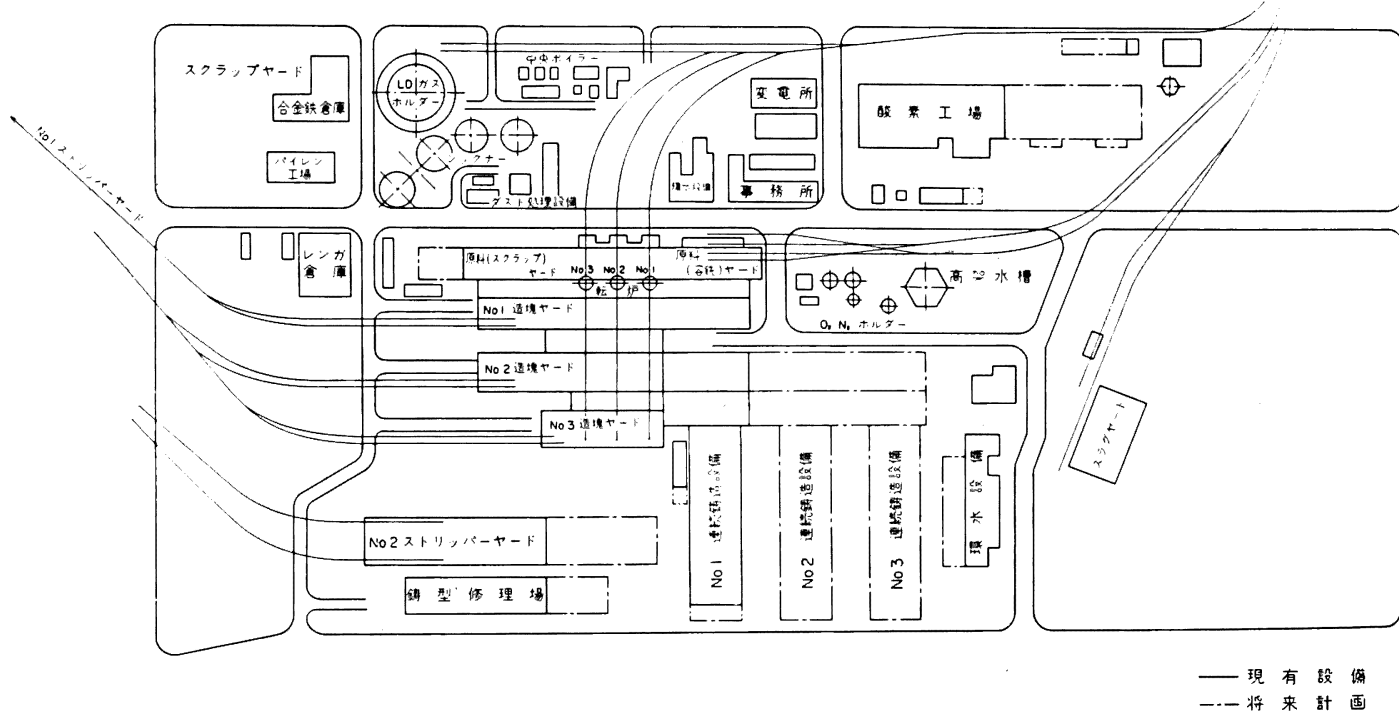

図6 第 1 製 鋼工場配置図

でも，普通鋼特にストリップ材の大半を占めるリムド鋼 の連続鋳造はなお当分の間困難と見られるので，この銅 種については従来どおり分塊ミルで処理することとし， 他は㥛力連続鋳造機にかけることにした. 現在子定して いる連鋳機は表 10 に示すとおりである.連鋳機の操業 技術の進歩により，その生産能力はさらに増大すること が予想されるが，後述する分塊能力から見て，連鋳の全 年間能力は少なくとも 450 万 $\mathrm{t}$ は必要である。これは全
粗鋼生産の約 40\% を占めることになり，製造コストの 低減に大きく寄与することになろう.

第 1 転炉工場は 550 万 $\mathrm{t}$ /year の能力をもつが，ここ に 3 基の連鋳設備をおいて，通常の造塊設備とあわせて 溶鋼を処理する計画であるが，昨年 6 月末に完成稼動し た第 1 連鋳機はまずブルーム用とした. それは次のよう な理由による。

（1）ビレット:ブルームの連鋳はすでに実績が多く 
安定した操業をしており，他社から購入したブルームの 実駼結果からみても，設備技術および材質の面で問題の ない水準に達していると判断された.

（2）当所第 1 分塊で圧延しているブルームを連鋳に 置き換えることにより，分塊能力が大幅に増大する。

（3）建設当初は本連鋳機の能力を 5 万 $\mathrm{t} /$ month と 推定していたが, 社内所要ブルーム量はこれを上迴ると 予想されたので，連鋳機の生産量が制約されることはな い.また当時はスラブ連鋳の実績が少なく，とくにリム ド鋼などの製造技術面で問題が残されている.

第 1 連鋳機の設備諸元は表 11 に示すとおりである. 操業開始後 1 力月足らずで 1 ヒート 8 ストランドの完全 注入に成功し, 生産量は逐月増大して現在棒鋼線材用お よびジュニャーH形鋼用素材を 4.5 万 $\mathrm{t} /$ month のベー スで生産しており，鋼種を次第に高炭素鋼の分野に拡大 しつつある. 操業開始以来の操業経過を表 12 に示す.

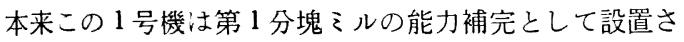
れたものであるが，その操業経験を通して水島製鉄所の 連鋳設備の拡充のみならず，千葉製鉄所の連鋳計画にも 資する役割を果たしているわけである.

\section{4 溶銑バランス}

4 基の高炉から生産される年間 950 万 $\mathrm{t}$ の溶銑は，つ ぎように配分されることになる。

\section{$6 \cdot 4 \cdot 1$ 直鋳工場向け}

従来社内の製鋼用鋳型および定盤は当社知多工場の鋳 鉄工場で製造していたが，製造コストを低減するため， 当所内に製鋼用溶銑を使用する直鋳工場を昭和 42 年 11 月

表 11 第 1 連鋳設備諸元

\begin{tabular}{|c|c|}
\hline 型 式 & ブルーム用全䈍曲型 \\
\hline ストランド数 & 8 本 \\
\hline タンディッシュ & $\begin{array}{l}4 \text { ストランド用 } \\
\quad(\text { 容量 } 12 \sim 14 \mathrm{t}) \times 2 \text { ケ }\end{array}$ \\
\hline $\begin{array}{l}\text { 搆造 : } \\
\text { 操業床高さ } \\
\text { 彎曲半径 }\end{array}$ & $\begin{array}{r}\mathrm{F} \mathrm{L}+13500 \mathrm{~mm} \\
12500 \mathrm{~mm}\end{array}$ \\
\hline 取 鍋 容 量 & 1 回あたり $200 \mathrm{t}$ （ノズル 2 本） \\
\hline 銅 片 寸 法 & $\begin{aligned} & 4 \text { サイズ }\left\{\begin{array}{ll}200 \mathrm{~mm} & \times 220 \mathrm{~mm} \\
200 & \times 300 \\
250 & \times 250 \\
250 & \times 300\end{array}\right\} \times \\
& 3000 \sim 10500 \mathrm{~mm}\end{aligned}$ \\
\hline 鋳 込 鋼 種 & 普通炭素鋼 $(0.07 \sim 0.85 \% \mathrm{C})$ \\
\hline 切 断 機 & メッサー式トーチ・カッター \\
\hline $\begin{array}{l}\text { ホット } \\
\text { スカーフォー }\end{array}$ & $\begin{array}{l}\text { スカーフ可能サイズ } 150 \mathrm{~mm} \times 150 \\
\mathrm{~mm} \sim 300 \mathrm{~mm} \times 300 \mathrm{~mm} \\
\text { スカーフ厚み } 5 \mathrm{~mm} \text { 以下 } \\
\text { スカーフスピート } 5 \sim 70 \mathrm{~m} / \mathrm{min}\end{array}$ \\
\hline
\end{tabular}

に建設して，それらの製造を逐次これに切替えていき， 将来月産 2 万 $\mathrm{t}$ の規模に拡大して, 全社の所要鋳型類を 自給する計画である。したがつて製品歩留を $90 \%$ とす れば年間溶銑所要量は約 27 万 $\mathrm{t}$ となる.

$6 \cdot 4 \cdot 2$ 電気炉向け

電気炉鋼年産 20 万 t , 溶銑配合率 $25 \%$ とすれば, 所要溶銑量は約 5.5 万 $\mathrm{t}$ と計上される.

$6 \cdot 4 \cdot 3$ 転炉向け

前記 2 工場の所要溶銑量を差引くと, 転炉向けの溶銑 は年間 918.5 万 $\mathrm{t}$ となる. 転炉における製鋼歩留を 92 $\%$ とし, 転炉鋼の年間生産量を 1100 万 $\mathrm{t}$ とすれば，溶 銑配合率は約 $77 \%$ となり転炉操業上問題はない。

\section{5 スクラップ需給}

粗鋼年間約 1100 万 $\mathrm{t}$ の生産時のスクラップ所要量は 前述の溶銑バランスの場合と同様な計算によれば，年間 約 290 万 $\mathrm{t}$ となる. これに対し場内発生の還元履および 廃却鋳型は，合計約 175 万 $\mathrm{t}$ と見積もることができるの で，年間約 115 万 $\mathrm{t}$ のスクラップ購入が必要である.こ の䝼入スクラップは，ほとえど船で入荷することにな るが，スクラップ用岸壁は既設の延長 $500 \mathrm{~m}$, 水深一 $7 \cdot 5 \sim 11 \cdot 5 \mathrm{~m}$ で 3 万 $\mathrm{t}$ 級船の着岸も可能で，十分荷揚げ の能力がある. またスクラップ置場は, 同岸壁の背後に 約 5 万 $\mathrm{m}^{2}$, その他製鋼工場周辺などに 10 万 $\mathrm{m}^{2}$ を確保し てある・スクラップはダンプカーに積み込み，製鋼工場 内に搬入する方式をとつている：

\section{7. 压延設備}

1100 万 $\mathrm{t}$ プラントの圧延設備としては, 当所での建 設の時期こそ遅れはしたが，その主体は何といつてもス トリップ・ミルで，それに瀬戸内各造船所を対象とした 厚板工場, 当社形鋼製品の品種拡大它目指す大形, 中形 工場，そして棒鋼，線材工場を付加するといつた規模と なる.

\section{$7 \cdot 1$ 分塊設備}

分塊設備は，表 13 に示すように 3 工場からなり，そ の圧延能力は年間 870 万 $\mathrm{t}$ となるが，第 3 分塊は後述の ように主として連鋳と鋼片ミルとの間に介在する性質の ものであるので, これを除外すれば 740 万 $\mathrm{t}$ となり, 連 鋳能力と合わせて約 1200 万 $\mathrm{t}$ となつて, 能力に若干の 余裕を持つことになる.

\section{$7 \cdot 1 \cdot 7$ 第 1 分塊工場}

本工場は全社の分塊能力不足に対処して，一貫体制が 確立する前年, 昭和 41 年 8 月に完成されたものである.

均熱师は当社で始めて上部一方焚換熱式を採用し, シ ヤック式メタリック・レキュペレーターを使用してお り，1基あたり 4 ホールからなり，転炉 1 ヒート $200 \mathrm{t}$ 分をホールに装入できる。当初は重油を燃料としたが， 第11高炉火入れ後はうックス・ガスを使用している. 当 初 8 ホール, 現在は16ホールでフル稼動中である. 
表 12 第 1 連続鋳造機の操業経過

\begin{tabular}{|c|c|c|c|c|c|c|c|c|c|c|c|c|c|}
\hline & & \multicolumn{2}{|c|}{$\mathrm{S} 43 / 7$ 月 } & \multicolumn{2}{|c|}{8 月 } & \multicolumn{2}{|c|}{9 月 } & \multicolumn{2}{|c|}{ 10月 } & \multicolumn{2}{|r|}{ 11月 } & \multicolumn{2}{|c|}{ 12月 } \\
\hline \multicolumn{2}{|c|}{$\begin{array}{r}\text { 注入チャージ数 } \\
\text { 注入完了 } \\
\text { 注入未完 }\end{array}$} & $\begin{array}{c}24 \mathrm{ch} \\
20 \\
4\end{array}$ & $\begin{array}{l}\% 3 \cdot 3 \\
16 \cdot 7\end{array}$ & $\begin{array}{l}49 \mathrm{ch} \\
43 \\
6\end{array}$ & $\left|\begin{array}{r|}\% \\
87 \cdot 8 \\
12 \cdot 2\end{array}\right|$ & $\begin{array}{l}56 \mathrm{ch} \\
55 \\
1\end{array}$ & $\begin{array}{r}\% \\
98 \cdot 2 \\
1 \cdot 8\end{array}$ & $\begin{array}{l}96 \mathrm{ch} \\
92 \\
4\end{array}$ & $\begin{array}{r}\% \\
95 \cdot 8 \\
4 \cdot 2\end{array}$ & $\begin{array}{r}112 \\
103 \\
9\end{array}$ & \begin{tabular}{r|r}
92 \\
7
\end{tabular} & \begin{tabular}{r|r}
$\%$ & $86 c$ \\
$2 \cdot 3$ & 82 \\
$7 \cdot 7$ & 4
\end{tabular} & $\begin{array}{c}\% \\
95 \cdot 4 \\
4 \cdot 6\end{array}$ \\
\hline $\begin{array}{l}\text { 未 } \\
\text { 完 } \\
\text { 内 } \\
\text { 訳 } \\
\end{array}$ & $\begin{array}{l}\text { 鍋ストッパー } \\
\text { ノズル詰り } \\
\text { その他(実験) }\end{array}$ & $\begin{array}{l}0 \mathrm{ch} \\
0 \\
4\end{array}$ & $\begin{array}{r}0 \\
0 \\
16 \cdot 7\end{array}$ & $\begin{array}{l}2 \mathrm{ch} \\
4\end{array}$ & $\left\{\begin{array}{l}4 \cdot 1 \\
8 \cdot 1\end{array}\right.$ & $\begin{array}{l}0 \operatorname{ch} \\
0 \\
1\end{array}$ & $\begin{array}{r}0 \\
0 \\
1 \cdot 8\end{array}$ & $\begin{array}{l}1 \mathrm{ch} \\
2 \\
1\end{array}$ & $\begin{array}{l}1 \cdot 0 \\
2 \cdot 1 \\
1 \cdot 0\end{array}$ & $\begin{array}{l}4 \\
1 \\
4(2\end{array}$ & & 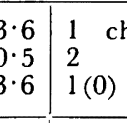 & $\begin{array}{l}1 \cdot 1 \\
2 \cdot 3 \\
1 \cdot 1\end{array}$ \\
\hline \multicolumn{2}{|c|}{ 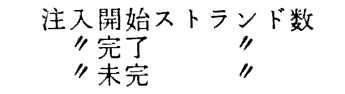 } & \begin{tabular}{c|}
191 本 \\
127 \\
64
\end{tabular} & $\begin{array}{l}6 \% \\
66 \cdot 1 \\
33 \cdot 9\end{array}$ & $\begin{array}{c}390 \text { 本 } \\
335 \\
55\end{array}$ & $\mid \begin{array}{l}\% 6 \cdot 0 \\
14 \cdot 0\end{array}$ & $\begin{array}{l}429 \text { 本 } \\
408 \\
21\end{array}$ & $\begin{array}{c}\% \\
95 \cdot 6 \\
4 \cdot 4\end{array}$ & \begin{tabular}{c|}
730 本 \\
678 \\
52
\end{tabular} & $\begin{array}{c}\% \\
92 \cdot 9 \\
7 \cdot 1\end{array}$ & $\begin{array}{r}847 \\
765 \\
82\end{array}$ & & \begin{tabular}{c|c}
$\%$ & 653 本 \\
$\cdot 3$ & 606 \\
$\cdot 7$ & 47
\end{tabular} & $\begin{array}{c}9 \% \\
7 \cdot 8^{2}\end{array}$ \\
\hline $\begin{array}{l}\text { 未 } \\
\text { 完 } \\
\text { 内 } \\
\text { 訳 }\end{array}$ & $\begin{array}{l}\text { 取鍋ストッパ事故 } \\
\text { ノズル詰り } \\
\text { ブレークアゥト } \\
\text { 電気事故 } \\
\text { 機械事故 } \\
\text { オーパーフロー } \\
\text { その 他 }\end{array}$ & \begin{tabular}{c|c}
10 本 & \\
41 & 2 \\
3 & \\
1 & \\
1 & \\
4 & \\
4 &
\end{tabular} & $\begin{array}{c}5 \cdot 2 \% \\
21 \cdot 8 \\
1 \cdot 6 \\
0 \cdot 5 \\
0 \cdot 5 \\
2 \cdot 1 \\
2 \cdot 1\end{array}$ & $\begin{array}{l}12 \text { 本 } \\
26 \\
5 \\
2 \\
2 \\
6 \\
2\end{array}$ & $\begin{array}{l}30 \% \\
6 \cdot 7 \\
1 \cdot 3 \\
0 \cdot 5 \\
0 \cdot 5 \\
1 \cdot 5 \\
0 \cdot 5\end{array}$ & $\begin{array}{l}0 \\
9 \\
1 \\
1 \\
3 \\
7 \\
0\end{array}$ & $\begin{array}{l}0 \% \\
1 \cdot 6 \\
0 \cdot 2 \\
0 \cdot 2 \\
0 \cdot 7 \\
1 \cdot 7 \\
0\end{array}$ & \begin{tabular}{c|}
9 本 \\
28 \\
7 \\
2 \\
4 \\
2 \\
0
\end{tabular} & $\begin{array}{l}1 \cdot 3 \% \\
3 \cdot 8 \\
0 \cdot 9 \\
0 \cdot 3 \\
0 \cdot 5 \\
0 \cdot 3 \\
0\end{array}$ & $\begin{array}{r}44 \\
26 \\
6 \\
1 \\
2 \\
3 \\
0\end{array}$ & $\left|\begin{array}{l}5 \cdot 2 \% \\
3 \cdot 1 \\
0 \cdot 7 \\
0 \cdot 1 \\
0 \cdot 2 \\
0 \cdot 4 \\
0\end{array}\right|$ & $\begin{array}{l}.2 \% \\
.1 \\
.7 \\
.1 \\
2 \\
.4 \\
0\end{array}$ & $\begin{array}{l}2 \cdot 3 \% \\
3 \cdot 5 \\
0 \cdot 9 \\
0 \cdot 1 \\
0 \cdot 1 \\
0 \cdot 3 \\
0\end{array}$ \\
\hline & & \multicolumn{3}{|c|}{ S 44/ 1 月 } & \multicolumn{2}{|c|}{2 月 } & \multicolumn{2}{|c|}{3 月 } & \multicolumn{3}{|c|}{4 月 } & \multicolumn{2}{|c|}{5 月 } \\
\hline \multicolumn{2}{|c|}{$\begin{array}{r}\text { 注入チ+ージ数 } \\
\text { 注入完了 } \\
\text { 注入末完 }\end{array}$} & $\begin{array}{l}142 \mathrm{ch} \\
133 \\
9\end{array}$ & \multicolumn{2}{|c|}{$\begin{array}{c}\% \\
93 \cdot 8 \\
6 \cdot 2\end{array}$} & $\begin{array}{l}175 \mathrm{ch} \\
163 \\
12\end{array}$ & $\begin{array}{c}\% \\
92 \cdot 8 \\
7 \cdot 2\end{array}$ & $\begin{array}{l}192 \mathrm{ch} \\
183 \\
9\end{array}$ & $\begin{array}{r}\% \\
95 \cdot 3 \\
4 \cdot 7\end{array}$ & \multicolumn{2}{|c|}{$\begin{array}{l}197 \mathrm{ch} \\
19 \mathrm{i} \\
6\end{array}$} & $\begin{array}{c}\quad \% \\
97 \cdot 0 \\
3 \cdot 0\end{array}$ & $\begin{array}{l}23 \varepsilon \mathrm{ch} \\
229 \\
9\end{array}$ & $\begin{array}{c}\% \\
96 \cdot 2^{2} \\
3 \cdot 8\end{array}$ \\
\hline $\begin{array}{l}\text { 未 } \\
\text { 完 } \\
\text { 内 } \\
\text { 訳 } \\
\end{array}$ & $\begin{array}{l}\text { 鍋ストッパー } \\
\text { ノズル詰り } \\
\text { その他(実験) }\end{array}$ & $\begin{array}{l}2 \mathrm{ch} \\
4 \\
3(0)\end{array}$ & $\begin{array}{l}1 \cdot \\
2 \cdot \\
2 \cdot\end{array}$ & & $\begin{array}{l}2 \mathrm{ch} \\
6 \\
5(2)\end{array}$ & $\begin{array}{l}0 \cdot 9 \\
3 \cdot 4 \\
2 \cdot 9\end{array}$ & $\begin{array}{l}3 \mathrm{ch} \\
3 \\
3(3)\end{array}$ & $\begin{array}{l}1 \cdot 6 \\
1 \cdot 6 \\
1 \cdot 6\end{array}$ & $\begin{array}{l}2 \\
4 \\
0\end{array}$ & & $\begin{array}{r}1 \cdot 0 \\
2 \cdot 0 \\
0\end{array}$ & $\begin{array}{l}5 \mathrm{ch} \\
3 \\
1(1)\end{array}$ & $\begin{array}{l}2 \cdot 1 \\
1 \cdot 3 \\
0 \cdot 4\end{array}$ \\
\hline \multicolumn{2}{|c|}{$\begin{array}{l}\text { 注入開始ストランド数 } \\
\text { 注入完了ストラント数 } \\
\text { 注入末完ストラント数 }\end{array}$} & $\begin{array}{l}1097 \text { 本 } \\
1012 \\
85\end{array}$ & \multicolumn{2}{|c|}{$\begin{array}{c}92 \cdot 2^{\%} \\
7 \cdot 8\end{array}$} & $\begin{array}{c}1367 \text { 本 } \\
1253 \\
114\end{array}$ & $\begin{array}{c}\% \\
91 \cdot 6 \\
8 \cdot 4\end{array}$ & $\begin{array}{c}1478 \text { 本 } \\
1333 \\
145\end{array}$ & $\mid \begin{array}{l}\% \\
90 \cdot 0 \\
10 \cdot 0\end{array}$ & \multicolumn{2}{|c|}{$\begin{array}{c}1545 \text { 本 } \\
1438 \\
107\end{array}$} & $\begin{array}{c}\% \\
93 \cdot 1 \\
6 \cdot 9\end{array}$ & \begin{tabular}{|l|l}
1866 本 \\
1753 \\
113
\end{tabular} & $\begin{array}{c}\% \\
93 \cdot 8 \\
6 \cdot 2\end{array}$ \\
\hline $\begin{array}{l}\text { 末 } \\
\text { 完 } \\
\text { 内 } \\
\text { 訳 }\end{array}$ & $\begin{array}{l}\text { 取鍋ストッパ事故 } \\
\text { ノズ詰り } \\
\text { プレークゥト } \\
\text { 電気事故 } \\
\text { 機械事故 } \\
\text { オーハーーフー } \\
\text { その 他 }\end{array}$ & $\begin{array}{c}19 \text { 本 } \\
42 \\
9 \\
0 \\
6 \\
3 \\
6\end{array}$ & $\begin{array}{l}1 . \\
3 \cdot \\
0 .\end{array}$ & $\begin{array}{l}7 \% \\
8 \\
8\end{array}$ & $\begin{array}{l}31 \text { 本 } \\
58 \\
13 \\
2 \\
1 \\
2 \\
7\end{array}$ & $\begin{array}{l}2 \cdot 3 \% \\
4 \cdot 2 \\
0 \cdot 9 \\
0 \cdot 2 \\
0 \cdot 1 \\
0 \cdot 2 \\
0 \cdot 5\end{array}$ & $\begin{array}{l}24 \text { 本 } \\
69 \\
15 \\
1 \\
1 \\
35\end{array}$ & $\begin{array}{l}1 \cdot 6 \% \\
4 \cdot 7 \\
1 \cdot 0 \\
0 \cdot 1 \\
0 \cdot 1 \\
2 \cdot 4\end{array}$ & $\begin{array}{r}0 \\
2 \\
42\end{array}$ & & $\begin{array}{c}1 \cdot 0 \% \\
2 \cdot 3 \\
0 \cdot 8 \\
0 \\
0 \cdot 1 \\
2 \cdot 7\end{array}$ & $\begin{array}{l}32 \text { 本 } \\
32 \\
11 \\
4 \\
4 \\
30\end{array}$ & $\begin{array}{l}1.7 \% \\
1.7 \\
0.6 \\
0.2 \\
0.2 \\
1.6\end{array}$ \\
\hline
\end{tabular}

表 13 分塊設備能力

\begin{tabular}{cl|c|cc}
\hline \hline 工 & 場 & 能力 $(千 \mathrm{t} /$ 年) & 製 & 品 \\
\hline No 1 & 分塊 & 2400 & スラブ, ブルーム \\
No 2 公 & 5000 & スラブ \\
No 3 分塊 & 1300 & ビレット, 丸棒 \\
\hline \multicolumn{2}{c|}{ 計 } & 8700 & \\
\hline
\end{tabular}

压延機は日立製ハイ・リフト 2 重逆転式で $25 \mathrm{t}$ まで の鋼塊を処理することができ，厚板用スラブ・大形形鋼 用ビーム・ブランクおよび一部棒鋼線材用ブルームなど 多品種の製造を目的とし, 特に大形形鋼々ルの製品最大 寸法 $1010 \times 450 \mathrm{~mm}$ 用のビーム・ブランクが製造でき るよう考虑されている. 現在スラブのタンデム圧延を実 施しているが，さらに将来ブルームのパラレル压延も可 能になるよう設計されている。駆動モーターは $4000 \mathrm{~kW}$
2 基で，ハイ・リフト型圧延機としてはわが国最大級で あり，したがつてきわめて能率的な圧延が可能である.

この分塊工場の背後に䇟接して 3 棟のスラブャードが あり,ここを起点として厚板工場, 大形工場が配置され ている・

\section{$7 \cdot 1 \cdot 2$ 第 2 分塊工場}

今年 5 月末完成したこの工場は，本来ホット・ストリ ップミルにスラブを供給するよう計画されたものである が，目下当所厚板工場および千葉ホット向けを製造して いる. 図 7 に工場配置図を示寸。

均熱炉は第 2 転炉工場の 1 ヒート $250 \mathrm{t}$ 分を 1 ホール に装入しうる大型炉で, 上部一方焚き方式でレキュペレ ーターはシャック式ツインタイプを採用してある. 当初 2 基 8 ホールから出発し, 逐次增強して最終的には 8 基 32ホールを予定している.

圧延機は高能率のユニバーサル式で, 最大 $40 \mathrm{t}$ の鋼塊 


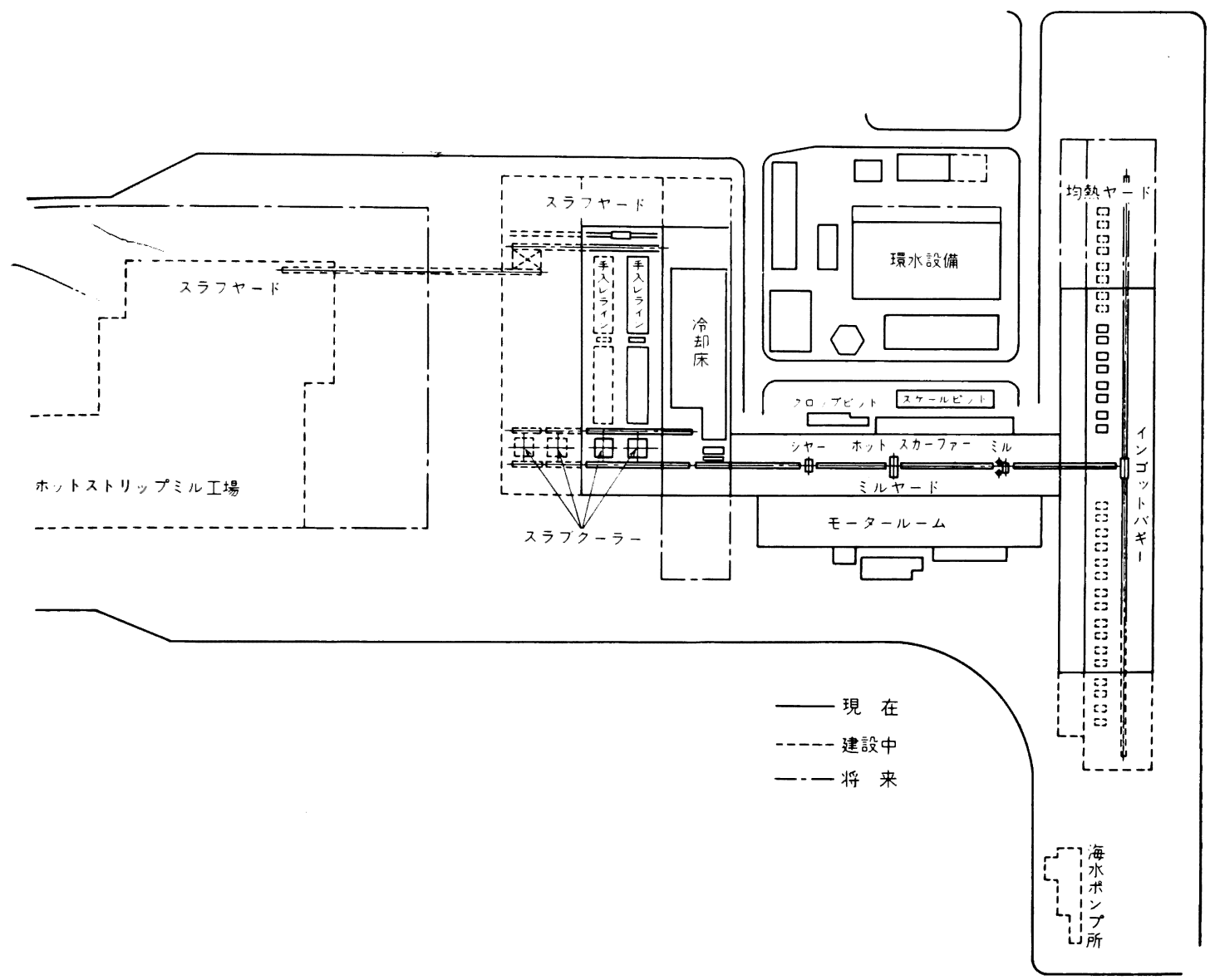

因 7 第 2 分塊工場配 置 図

を処理でき，本邦最大級のものである.

当工場の特徵として, 将来 500 万 $\mathrm{t}$ 以上の年間能力を 発揮しうるように, 全ラインにわたつて能率化の配虑が なされている.すなわち，

(1) 将来 2 台のインゴット・バギー, 2 面のインゴ ット・レシービンク・テーブル（うち一面は横行可能） を設置して, 鋼塊供給ピッチの短縮化を計ることができ る.

（2）主モーターのトルクは世界最大級であり，また フルタンデムあるいはオール・フラット圧延が可能であ る.

（3）ジーマグ社一住友機械工業(株)製の油圧駆動 4 列スポーク式スラブクーラー 4 基（当初 2 基）を備え, これにスラブ手入ラインを 2 連直結させ, さらにスラブ の自動科量, ホットストリップミル工場スラブヤードへ のベルトコンベヤ方式によるスラブ移送など工程の連続 化により，スラブ処理時間の短縮・作業面積の節減・作 業人員の削減および工程管理の効率化をはかつてある.
（4） APC，CPC など大幅な自動化の採用により， 要員の減少・作業の安定性を確保するほか, 各種情報伝 達・作業指示の自動化が図られている。

以上第 $1 \cdot 2$ 分塊工場の圧延機の仕様を表 14 に示し ておく.

\section{$7 \cdot 1 \cdot 3$ 第 3 分塊工場}

これは既設の鋼片ミルの前面に設置することを計画し ているもので, 鋼片ミルに供給する素材ブルームの大型 化による能率向上と, 知多工場に建設中のシームレス. パイプ・ミル用丸棒の一部を鋼塊より 1 ヒートで圧延す ることを组いとするもので，年間能力 130 万 $\mathrm{t}$ を見込え でいる、素材ブルームは将来設置予定の大型ブルーム連 鋳機で倛給与ることになつている.

\section{2 厚板工場}

本工場は当社茸合工場の 3 段厚板ミルをリプレースし て，水島一貫体制の一翼として昭和 42 年 4 月に建設され た. 当初は連続加熱师 1 基と仕上るルで月間 7 万 $\mathrm{t}$ の能 力で出発したが, 需要の増加に応じて逐次増強され, 来 
表 14 第 $1 \cdot 2$ 分塊ミルの仕様

\begin{tabular}{|c|c|c|c|c|c|}
\hline & \multicolumn{3}{|c|}{ 第 1 分 塊 } & & 2 分 塊 \\
\hline 式 & \multicolumn{3}{|c|}{ ハイ・リフト } & \multicolumn{2}{|c|}{ ユニパーサル式 } \\
\hline $\begin{array}{l}\text { ロール寸法 } \\
\text { 水平ロール } \\
\text { 竪型ロール }\end{array}$ & \multicolumn{3}{|c|}{$1350 \mathrm{~mm} \phi \times 3400 \mathrm{~mm}$} & \multicolumn{2}{|c|}{$\begin{array}{l}1300 \mathrm{~mm} \phi \times 2800 \mathrm{~mm} \\
1050 \mathrm{~mm} \phi \times 2280 \mathrm{~mm}\end{array}$} \\
\hline ロールリフト & \multicolumn{3}{|c|}{$2100 \mathrm{~mm}$} & \multicolumn{2}{|r|}{$2500 \mathrm{~mm}$} \\
\hline 使用 鋼 塊 & \multicolumn{3}{|c|}{$25 \mathrm{t} \quad(\max )$} & \multicolumn{2}{|c|}{$20 \sim 40 \mathrm{t} \quad(\max )$} \\
\hline \multirow[t]{4}{*}{ 製 品 寸 法 } & ブルーム & ビーム・ブランク & ス ラ ブ & \multicolumn{2}{|r|}{ スラブ } \\
\hline & \multirow{3}{*}{$\begin{array}{l}180 \times 200 \\
250 \sim 300\end{array}$} & \multirow{3}{*}{$\begin{array}{c}70 \times 2 \equiv 0 \times 500 \\
\sim 200 \times 50 \\
1300\end{array}$} & $100 / 300$ & 厚さ & $110 \sim 305$ \\
\hline & & & $1000 / 1900$ & 幅 & $600 \sim 2200$ \\
\hline & & & $1500 / 9200$ & 長さ & $12200 \max$ \\
\hline 製 作 会 社 & \multicolumn{3}{|c|}{ 日立製作所 } & \multicolumn{2}{|c|}{ 三菱重工業(株)-MESTA社 } \\
\hline 主 電 動 機 & \multicolumn{3}{|c|}{$4000 \mathrm{~kW} \times 2$} & \multicolumn{2}{|c|}{$5000 \mathrm{~kW} \times 23500 \mathrm{~kW} \times 1$} \\
\hline 圧 延 能 力 & \multicolumn{3}{|c|}{240 万 $\mathrm{t}$} & \multicolumn{2}{|c|}{ 当初 150 万 $t$ (最終500万 $t$ ) } \\
\hline
\end{tabular}

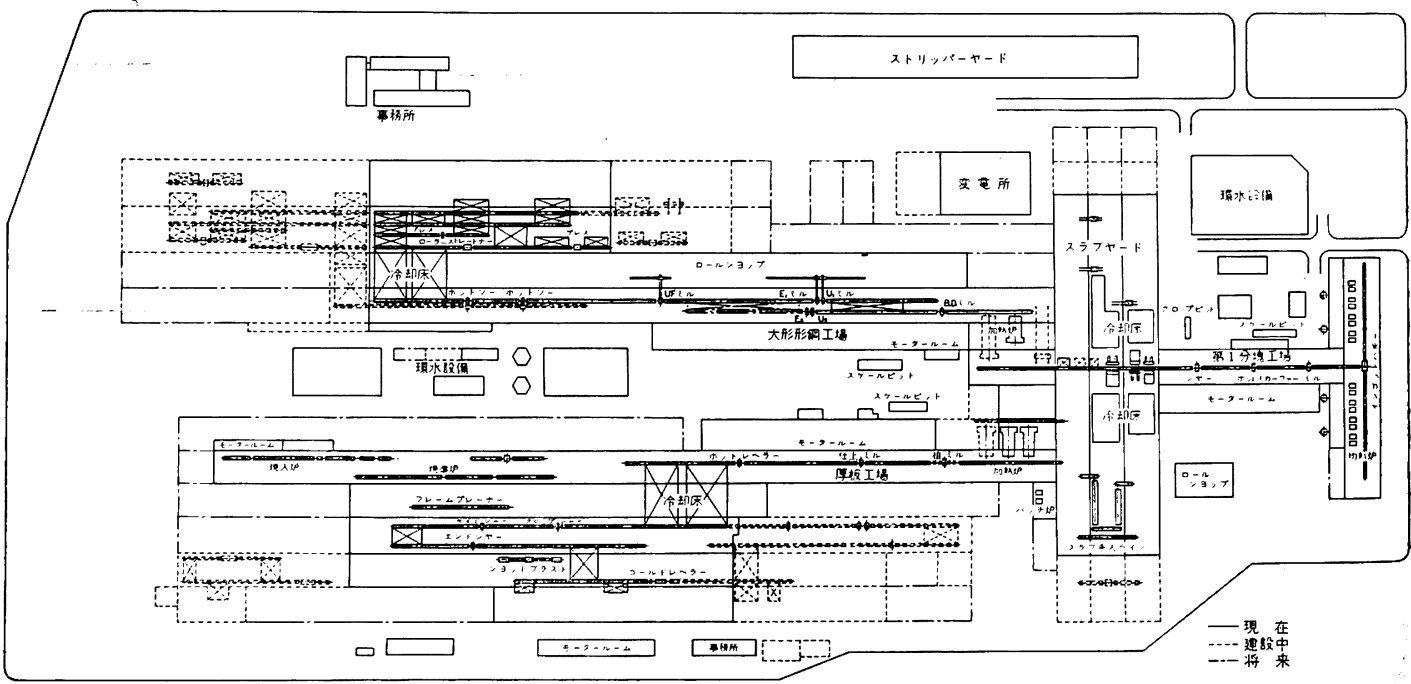

図 8 第 1 分塊, 厚板大形形鋼各工場配置図

年 7 月末粗圧延機の増設によつて最終能力 16 万 $\mathrm{t} / \mathrm{mon}-$ th に達する見込みである. 本工場 は第 1 分塊工場のス ラブヤードの西側から北の方に配置されており，その配 置図は図 8 に示すとおりである.

\section{$7 \cdot 2 \cdot 1$ 加熱炉}

現在連続加熱炉 2 基およびバッチ炉 1 基よりなるが， その主要仕様は表 15 のとおりであつて, 目下連続加熱 炉の 3 基目を建設中である. 連続加熱炉の特色としては

（1）スラブの表面疵をなくすため, 第 $1 \cdot 2$ 加熱炉
については耐熱合金製ホット・スキッドを採用してお り，建設中の加熱炉ではウオーキング・ビーム方式を採 用する。

（2）またどの加熱炉もデリベリ・テーブルへのスラ ブ押出しをやめ, スラブ・エキストラクターを備えてお り，スラブ表面疵発生を防いでいる.

（3）均熱帯がないため, 同一炉長に対して加熱能力 が非常に大きい。 
表15 加 熱炉 の 主要 仕 様

\begin{tabular}{|c|c|c|c|}
\hline & & 連 続 加 熱 炉 & ハ ッ チ 式 加 熱 炉 \\
\hline 型 & & 6 帯式ホット・スキッド & トップ・ワンウエイ上部開閉式 \\
\hline 基 & 数 & 2 基 & 2 基（ 2 ホール） \\
\hline 加 熱 能 & 力 & $150 \mathrm{t} / \mathrm{hr}$ & $8 \mathrm{t} / \mathrm{hr} \times 2$ \\
\hline 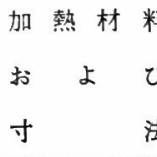 & $\begin{array}{l}\text { 料 } \\
\text { び } \\
\text { 法 }\end{array}$ & \begin{tabular}{ll} 
& \multicolumn{1}{c}{ ラ $7{ }^{\circ}$} \\
厚さ & $100 \sim 300 \mathrm{~mm}$ \\
幅 & $1000 \sim 1900$ \\
長さ & $1900 \sim 3200$ \\
重量 & $14 \cdot 1 \mathrm{t} \quad(\max )$
\end{tabular} & 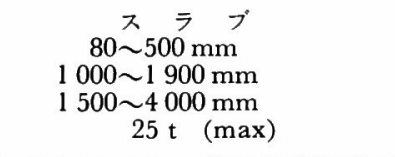 \\
\hline 使 用 燃 米 & 料 & 重油またはMガス & 重油またはMガス \\
\hline 製 作 会 社 & 社 & 呉 造 船 所 & 三菱 重 工 業 \\
\hline
\end{tabular}

表16 厚板仕上ミルの主要仕様

\begin{tabular}{|c|c|}
\hline 型 式 & 4 重逆転式 \\
\hline $\begin{array}{c}\text { ロール寸法 } \\
\text { ハックオップ } \\
\text { ロール } \\
\text { ワーク・ } \\
\text { ロール }\end{array}$ & $\begin{aligned} 1900 \mathrm{~mm} \phi & \times 4000 \mathrm{~mm} \\
\left(75^{\prime \prime}\right. & \left.\times 1571 / 2^{\prime \prime}\right) \\
1000 \mathrm{~mm} \phi & \times 4100 \mathrm{~mm} \\
\left(39^{\prime \prime}\right. & \left.\times 160^{\prime \prime}\right)\end{aligned}$ \\
\hline $\begin{array}{l}\text { ロール・ } \\
\text { リフト }\end{array}$ & $550 \mathrm{~mm}$ \\
\hline $\begin{array}{l}\text { 設 計 } \\
\text { 製作会社 }\end{array}$ & 石川島播磨重工業一SACK \\
\hline 主電動機 & $3750 \mathrm{~kW} \times 2$ 基 (三菱電機) \\
\hline $\begin{array}{l}\text { 製品寸法 } \\
\text { 厚さ } \\
\text { 幅 } \\
\text { 長さ }\end{array}$ & $\begin{array}{l}45 \sim 200 \mathrm{~mm} \\
3850 \mathrm{~mm} \text { (max) } \\
40 \mathrm{~m} \text { (max) }\end{array}$ \\
\hline
\end{tabular}

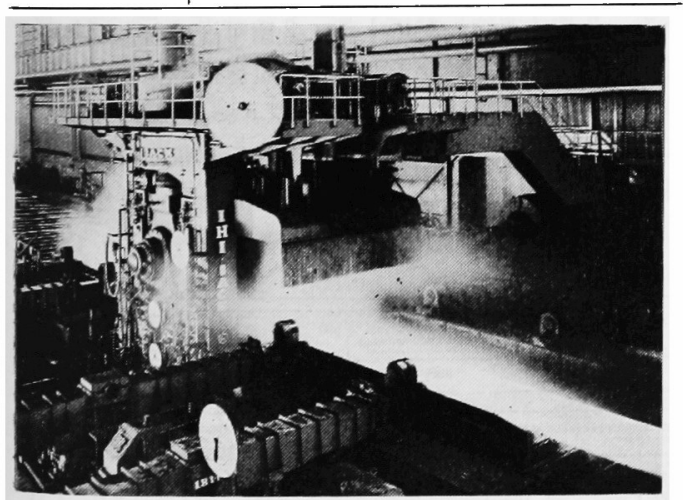

写真 4 厚板工場仕上压延機

\section{$7 \cdot 2 \cdot 2$ 厚板压延機}

仕上圧延機の主要仕様は表 16 に示す．その特徵はつ ぎのとおりである。

(1) バック・アップ・ロールの直径は $1900 \mathrm{~mm}$ で 世界最大級で，また八ウシング重量が $260 \mathrm{t}$ もるので ミル剛性が大で板幅方向の厚み精度が高い。
（2）日本で初めて A.G.C. 装置を設けており，板 の長さ方向の厚さを均一にすることができる.

（3）胴長 160 in は造船用鋼板を主体とする考えで あつたが，粗圧延機は胴長 180 in とし, 製品幅 $4 \mathrm{~m}$ 以 上の広幅鋼板の仕上圧延も行なわせ，最大幅 $4 \cdot 3 \mathrm{~m}$ の製 品も可能となる.

（4）ロール・クイック・チェンジ装置を設けて，口 一ル組替え時間を短緶している.

（5）デスケーリングの水圧を $150 \mathrm{~kg} / \mathrm{cm}^{2}$ にして， スケール除去をより効果的にしてある.

\section{$7 \cdot 2 \cdot 3$ 精整設備}

将来の能力增大に相応して, クーリング・ベッドは 2 面とし, 製品は泠却後左右に分かれて処理しうるよう配 置されている.クーリング・ベッドはウォーキング・ビ 一ム方式を採用して，スリ疵の防止をはかつており，ま た画期的なダウンカット・ツイン型式のサイド・シャー を備え，板厚 $40 \mathrm{~mm}$ までの剪断が容易である。このほ かショット・ブラストや熱処理設備など必要に応じて増 設中である。

本工場は日本で最初にコンピューター・システムを採 用し, プロセス・コンピューターにより同一ロット内の 製品間の板厚のバラツキを少なくし，才ペレーターの人 員の削減や人為的洖動作の防止, 压延スケジニールの合 理化に効果をあげている.

\section{3 大形形鋼工場}

当社は従来莫合工場においてシュニャーH形鋼の生産 を行なつているが, 需要の増大に対処しまたより大型の $\mathrm{H}$ 形鋼への進出を目指して昭和43年 6 月本工場を完成傢 動させた．本工場の榢動により当社は $100 \times 50 \mathrm{~mm}$ の中 形サイズから $1010 \times 450 \mathrm{~mm}$ までの全サイズのH形鋼 の製造が可能となり，さらに鋼矢板製造の計画も着々進。 行中である.

本工場はブレークダウン・ミル，ユニバーサル式組在 延機および仕上圧延機からなり，その配置図は図8 に示 


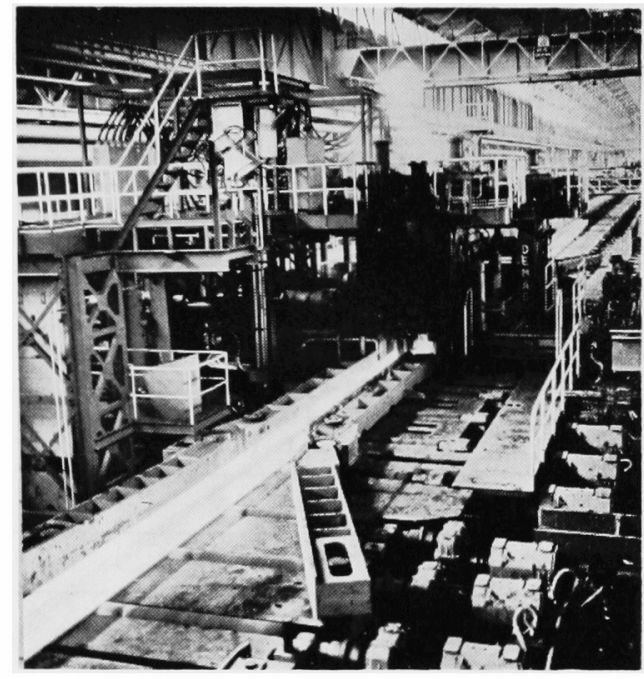

写真 5 大形工場

すとおりである. 工場の特徵としては

（1）加熱炉はウオーキング・ビーム方式で，材料の 疵発生を防ぐためエキストラクターを使用している。

（2）長尺ものの生産打よび歩留向上のため，圧延長 さ $100 \mathrm{~m}$ を基準として压延機を配置してある。

(3) 粗圧延機は大小 2 種類のスタンドおよびロール を有し， H形鋼の圧延寸法に応じて使い分けし，圧延洔 のロールの撓み・スタンドの歪みを少なくし，製品の寸 法精度の向上をはかつている.なお鋼矢板・丸棒など一 般形鋼圧延の際は, エッジング圧延機は形鋼ロールを用 いてストラクチュラルミルとして使用し，また仕上圧延 機には二重圧延機が使用される.

（4）多品種生産に対処するため, ロール組替にはス タンド交換方式を採用したので，ロール組替洔間および ロール調整のための休止洔間を大幅に短縮することがで きた。各スタンド下部に車輪を有し, 組替用レールを水 圧で押し上げてロールスタンドー式をロールショップに
引出し，あらかじめ用意した次サイズ用のロールスタン ドと交換しスタンド組替を行なう.スタンドの引出しは 電動式ドローイングカーで行ない，ロールショップヘの. 移動は横行移動台車による.

（5）クーリング・ベッドは形鋼設備としてわが国で はじめてウォーキング・ビーム方式を採用し, 製品のス リ疵発生防止に努めている。

（6）精整ヤードにおいては, クーリング・ベッドを 出た形鋼はロール稪正機, または油圧プレスで矯正され るが, 矯正工程の前後で流れ作業により，長さ・外観・ 断面寸法 ·形状の検査が行なわれる. その後仕わけ場に 送られ, 長さ別に仕わけられて必要数を機械的に結束し たうえ, 製品は向先別あるいは倉庫別に定められた位置 に置かれる、したがつて，このときには発送先が決めら れている.このように, 検査から出荷指示までのすべて の業務を工場内のラインで処理できるように, 設計され ている.

建設の当初は年間 48 万 $\mathrm{t}$ の能力であつたが, 逐次増 強して最終 100 万 $\mathrm{t}$ ベースにもつていく計画である. 現 有主要設備の内容を表 17 に示す.

\section{4 鋼片・線材工場}

冒頭にも述べたように, 水島製鉄所に最初に建設され た設備であつて，压延機としてはビレット・ミルと小形 ・線材ミルとからなる.ビレット・ミルは当社西宮工場 で遊休になつていたフープ用ミルを改造したものである が, 線材ミルは建設当時最新鋭の設備であつた. 本工場 の配置図を図 9 に示す.

\section{$7 \cdot 4 \cdot 1$ ピレットミル}

素材ブルームは当初圧延材現在は大半連鋳材を使用し 棒鋼線材用ビレット・中棒および平鋼の生産を行なつて いる. 3 帯式連続加熱炉 1 基, 2 重可逆式および非可逆 式粗圧延機各 1 スタンドおよび 2 重連続式仕上圧延機 6 スタンドの構成で, 年間60万 $\mathrm{t}$ (ブルーム換算)の能力゙を もつが, 将来本ミルのブレークダウンミルの役割をなす 第 3 分塊々ルを設置して, 素材ブルームを大形化し, 生

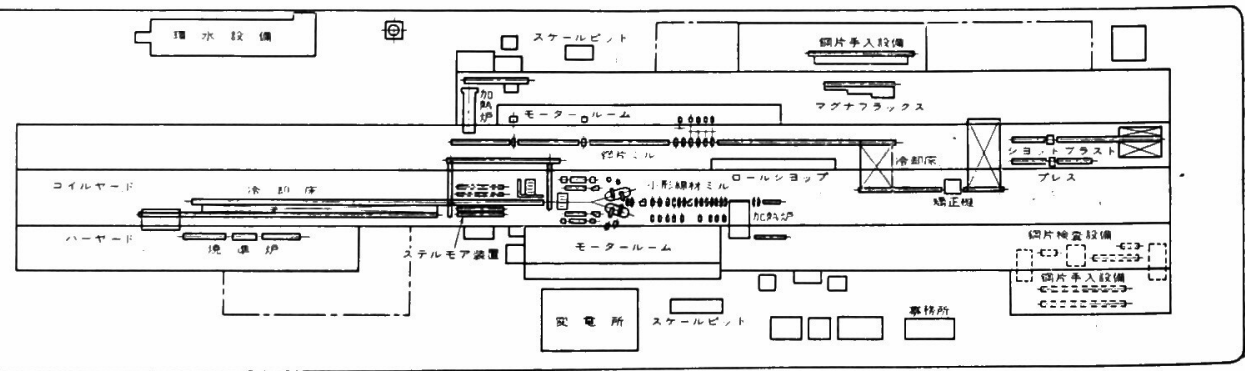

図 9 鋼片工場 小形線材工場配置図 
表17 大 形工場主 要設 備内 容

\begin{tabular}{|c|c|c|c|c|}
\hline 備 & 型 & 基 数 & 仕 & 設計 ·製作会社。 \\
\hline 加 & $\begin{array}{l}\text { 連続式 } \\
\text { ウォーキング } \\
\text { ビーム式 }\end{array}$ & $\left(\begin{array}{c}1 \\
\begin{array}{c}1 \\
\text { 基増設 }\end{array} \\
\text { 中 }\end{array}\right.$ & $\begin{array}{ll}\text { 加熱能力 } & 150 \mathrm{t} / \mathrm{hr} \\
\text { 加熱材料 ブルーム・ビームブランク } \\
\text { 㜣 料 重油またはMガス }\end{array}$ & 中外炉工業 \\
\hline ブレークダウンミル & $\left(\begin{array}{c}\text { 二重逆転式 } \\
\text { ルッッジャー) } \\
\text { 将来設置 }\end{array}\right.$ & 1 基 & $\begin{array}{lc}\text { ロール寸法 } & 1100 \phi \times 2800 \mathrm{~mm} \\
\text { ロールリフト } & \text { 上ロール } 1420 \mathrm{~mm} \\
& \text { 下ロール } 380 \mathrm{~mm} \\
\text { 主モーター } & 6000 \mathrm{~kW} \times 1 \text { 基 }\end{array}$ & $\begin{array}{l}\text { 石川島播磨重工業 } \\
\text {-SACK社 }\end{array}$ \\
\hline $\begin{array}{l}\text { 粗圧延機： } \\
\text { 1. } \quad \text { ユニシーサル式 } \\
\quad \text { 粗圧延機 }\end{array}$ & ユニバーサル式 & $\left(\begin{array}{c}1 \text { 基 } \\
\text { 将兽設 }\end{array}\right.$ & $\begin{array}{ll}\text { 小スタンド: } & \\
\text { 水平ロール } & 1320 \phi \times 226 \sim 557 \mathrm{~mm} \\
\text { 垂直ロール } & 880 \phi \times 410 \mathrm{~mm} \\
\text { 大茨 } & \\
\text { 水平ロール } & 1500 \phi \times 364 \sim 856 \mathrm{~mm} \\
\text { 垂直ロール } & 1000 \phi \times 520 \mathrm{~mm} \\
\text { 主モーター： } & 6200 \mathrm{~kW} \times 1 \text { 基 }\end{array}$ & $\begin{array}{l}\text { 日立造船一 } \\
\text { DEMAG社 }\end{array}$ \\
\hline 2. エッジング & 二重 式 & $\left(\begin{array}{c}1 \text { 基 } \\
\text { 将增設 } \\
\text { 設 }\end{array}\right)$ & $\begin{array}{ll}\text { エッジャーロール } & 1150 \phi \times 2500 \mathrm{~mm} \\
\text { 形鋼ロール } & 1050 \phi \times 2500 \mathrm{~mm} \\
\text { 主モーター: } & 1000 \mathrm{~kW} \times 2 \text { 基 }\end{array}$ & \\
\hline 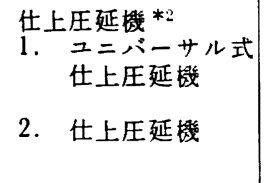 & ユニパーサル式 & 1 基 & $\begin{array}{ll}\text { 水平ロール } & \begin{array}{l}1320 \phi \times 225 \sim 856 \mathrm{~mm} \\
\text { 垂直ロール } \\
\text { 主モーター }\end{array} \quad \begin{array}{l}880 \phi \times 410 \mathrm{~mm} \\
830 \phi \times 480 \mathrm{~mm} \\
3100 \mathrm{~kW} \times 1 \text { 基 }\end{array} \\
\text { 形鋼ロール } & 1050 \phi \times 2500\end{array}$ & $\begin{array}{l}\text { 日立造船一 } \\
\text { D E M A G 社 }\end{array}$ \\
\hline
\end{tabular}

*1 $\left\{\begin{array}{l}\text { エッジャーロール……形鋼压延時に使用 } \\ \text { 形鋼ロール………他の形鋼压延時に使用 }\end{array}\right.$

*2 $\{$ ユニハーールル式仕上ミル……形錀圧延時に使用

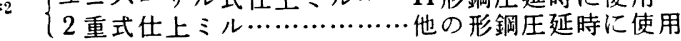

表18 線材ミルの䓯成

\begin{tabular}{|c|c|}
\hline 型式 & モルガン・ジーマグ式水平全連続式 \\
\hline $\begin{array}{l}\text { 粗 压 延 機 } \\
\text { 第1 中間压延機 } \\
\text { 第 } 2 \text { 中間压延機 } \\
\text { 吉上压 延 機 }\end{array}$ & 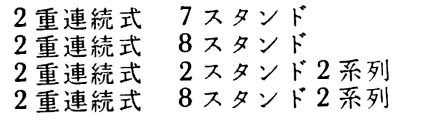 \\
\hline
\end{tabular}

産能力を 130 万 $\mathrm{t}$ /year に引きあげる計画である。

7.4 .2 小形線材之ル

本ミルは表 18 に示すように 25 スタンドよりなる水 平全連続式であり，5～ $50 \mathrm{~mm}$ の線材・棒鋼の生産が可 能であつて，圧延速度最高 $40 \mathrm{~m} / \mathrm{sec}$ 新鋭設備である。

当初 5〜10 min の線材については 2 ストランド压延で あつたが，昨年 9 月仕上王延機 1 系列の增設により 4 ス トランド圧延が可能となり，年間能力も 36 万 $\mathrm{t}$ から 42 万七増大した。 上述のように圧延は $\mathrm{H}-\mathrm{H}$ 方式である か，第 2 中間および仕上圧延機群に，圧延ロールが直接 リンクで連結された特殊構造のウィルソン・スタンドを 採用しているので，压延中のロール間腙の变化がきわめ て小で，高速圧延が可能であるとともに，製品の精度が 高い。また昨年 9 月 No 13・15 スタンドに堅ロールを 増設して，圧延精度を高めた。

本圧延機淎鋼・線材のコンビネーション・ミルであ
るため，挚取機のほかに直棒用クーリング・テーブルを 備えてある. 一方線材に対しては, 压延機出側コンベヤ にリング状に分有し，压延忉の保持する熱を利用して強 制通風冷却により熱処理するステルモア設㒉 2 系列を昨 年 9 月新設した。これにより次工程における熱処理を省 略しうるばかりでなく，均質な高級線材の生産が可能と なつた．近くさらに 2 系列を增設する計画である.

この工場は将来棒鋼専用ミルを新設するときに線材専 用えルにする考えである。

\section{5 ホットストリップ工場}

待望のホットストリップ・ミルは昭和 43 年 6 月着工し 明年 1 月完成の予定である. 本えルは全連続式の $90 \mathrm{in}$ 世界最大級の設備で，ミル能力は最終 500 万 $\mathrm{t} /$ year と なるが，当初は 150 万 $\mathrm{t}$ 程度から出発し逐次增強してい く計画である. 本設備は稼動開始時粗圧延機 4 基（将来 5 基）・仕上王延機 6 基（将来 8 基）からなり，仕上仕 延機にはA.G.C. 装置を設置するとともに, 全スタン ドにワークロール・ベンディング装置などを設けて，板 厚精度・形状など製品の品質向上をはかることにしてい る.

本工場は第 2 分塊工場のスラブヤードを出発点として 压延ラインが北方に伸び，圧延されたコイルはコイルカ 一またはコンベヤーで別棟のコイル・ストレージ・ヤー 


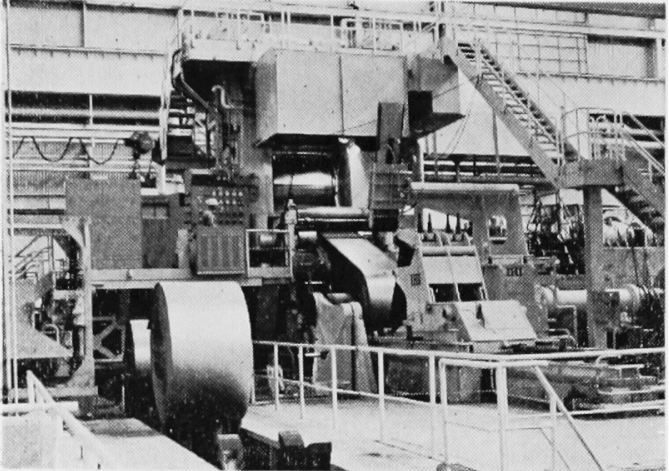

写真 6 冷压工場スキンパスミル

ドに搬送される。コイル重量は第 2 分塊経由のものにつ いては最大 $40 \mathrm{t}$ ，スラブ連鋳材を使用するときは $45 \mathrm{t}$ ま で処理できるようになつている.

\section{6 コールドストリップエ場}

最終的にはコールドストリップ・ミルは 2 基を計画し ているが，1 号機は 68 inの 5 タンデムミルとした. 当 社の冷圧設備のうち, 暁鈍およびスキンパスの能力が在 延能力に比べて不足していたので, タンデム・ミルの完 成に先行して, 本年 3 月クリーニング・ライン, 焼鈍設 供・スキンパスミルその他付帯設備を完成稼動させて, 千葉で压延したコイルの処理を行なつている.タンデム ミルは本年 9 月末完成予定で, 当初年産 36 万 $\mathbf{t}$ の能力 から出発し, 最終 100 万 $\mathrm{t}$ ベースに増強する計画であ る. 本えルはロール圧下装置に全面油圧方式が採用され ているのが特徵で, 高速圧下, ロール偏心補正その他が 可能で, A.G.C. 装置・ロールクラウンのコントロール とあわせて, 精度の高い形状のよい製品の生産が可能と なる.またコイルの自動搬送・自動通板など機械化・自 動化を積極的に採用してある。

2 号機のミルについてはロール幅など未定であるが， 年間 120 万 $\mathrm{t}$ 程度の能力を子定している。

\section{$7 \cdot 7$ その他計画中の压延設備}

上記のほかに現在計画中で一期工事完了点でに建設を 予定している压延設備を列挙寸ると, 次のとおりであ る.

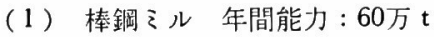

(2) 線材之ル 年間能力 : 50万 $\mathrm{t}$

(3) 中形之ル 年間能力 : 60万 $\mathrm{t}$

各々ルの年間能力は現時点での推定で, 今後計画の段 階では若干の变更は琼りうる.

\section{$\mathbf{7 . 8}$ 総 括}

以上の压延設備が計画どおり完成し，粗鋼年産 1100 万 $\mathrm{t}$ の規模で高炉から最終製品まで, 能力的に若干の余 裕をもつて釣合いがとれた時点において，製鋼から各圧 延設備にいたる工程の流れを示すと図 10 のとおりであ る.ここで示す数値は概略値であつて, 実際上は多少の
変動はありうる。概括的にいえば, ストリップおよび厚 板ミルはほとえどフル稼動とし，形鋼・棒鋼などについ ては稼動率 80〜85\% 程度に考えている.

\section{8. 鋳鍛鋼 工場}

当社兵庫工場は前述のように鋳鍛鋼製造の歴史が古 く，それだけに設備は老朽しており，新設備に更新する にも，敷地建屋の制約があつて抜本的なことはむずかし く今までは部分的改良に終始してきた。一方鋳鍛鋼の大 口需要家である造船界は, 最近急速に船舶の大型化の方 向に進み，兵庫工場の現有設備ではこれに追随できず， せいぜい 10 万 $\mathrm{t}$ 前後の船舶部品しかまかなえない状態 になつた。そこで水島製鉄所の北部地区に最新鋭の鋳鍛 鋼専門工場を建設し, 逐次兵庫工場を閉鎖していくこと になつた。

この鋳鍛造工場は製鋼・鋳造・鉒造・機械加工および ビルドアップなどからなるが，現在建設中で本年 7 月末 完成予定の設備としては, 既述の電気炉工場を除くと次 のとおりである。

(1) 鉡鋼工場

月 $300 \mathrm{t}$ 程度の能力をもつ鋳鋼各設備 1 式

（2）鍛造工場

$6000 \mathrm{t}$ 水压プレス 1 基

台車式加熱炉および熱処理炉各 5 基

焼入油槽

2 基

（3）機械加工および組立工場

大型旋盤

1 台

舭頭材加工機

1 台

横中ぐり盤

1 台

芯出定盤

1 面

組立フロアー

2 面

$1000 \mathrm{t}$ 製缶用プレス

1 基

鍛造工場の中心となる $6000 \mathrm{t}$ プレスは西独 Hydraulik 社製の最新式プレスで，その仕様は表 19 に示す.

これらの設備の完成により, 鋳鋼品は従来の最大 $45 \mathrm{t}$ から $120 \mathrm{t}$ へ, また鍛造品は往来 $26 \mathrm{t}$ が限界であつた のが，最大鋼塊 $200 \mathrm{t}$ を使用して $120 \mathrm{t}$ をで製造可能と なる. 亡たビルド・アップ製品は兵庫での最大 $75 \mathrm{t}$ が $270 \mathrm{t}$ に, 将来 $320 \mathrm{t}$ に拡大される. したがつて船舶部

表19 $6000 \mathrm{t}$ プレスの主要仕様

\begin{tabular}{|c|c|}
\hline 型 & 4 柱式プッシュ・ダウン型 \\
\hline & $\begin{array}{l}2100 \mathrm{t} / 4200 \mathrm{t} / 6300 \mathrm{t} / 7500 \mathrm{t} \\
4 \text { 段階切換式 }\end{array}$ \\
\hline 歌 動 方 & 純水圧了キュムレータ一駆動 \\
\hline F 1 ᄀ 1 ト & $6000 \mathrm{~mm}$ \\
\hline 支柱内側有効寸法 & $4900 \times 2200 \mathrm{~mm}$ \\
\hline 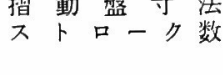 & $\begin{array}{l}\text { 粗鍛造時 } 18 \sim 19 \text { 回 } / \min \\
\text { 仕上鍛造時(自動) } 50 \sim 60 \text { 回 } / \mathrm{min}\end{array}$ \\
\hline
\end{tabular}



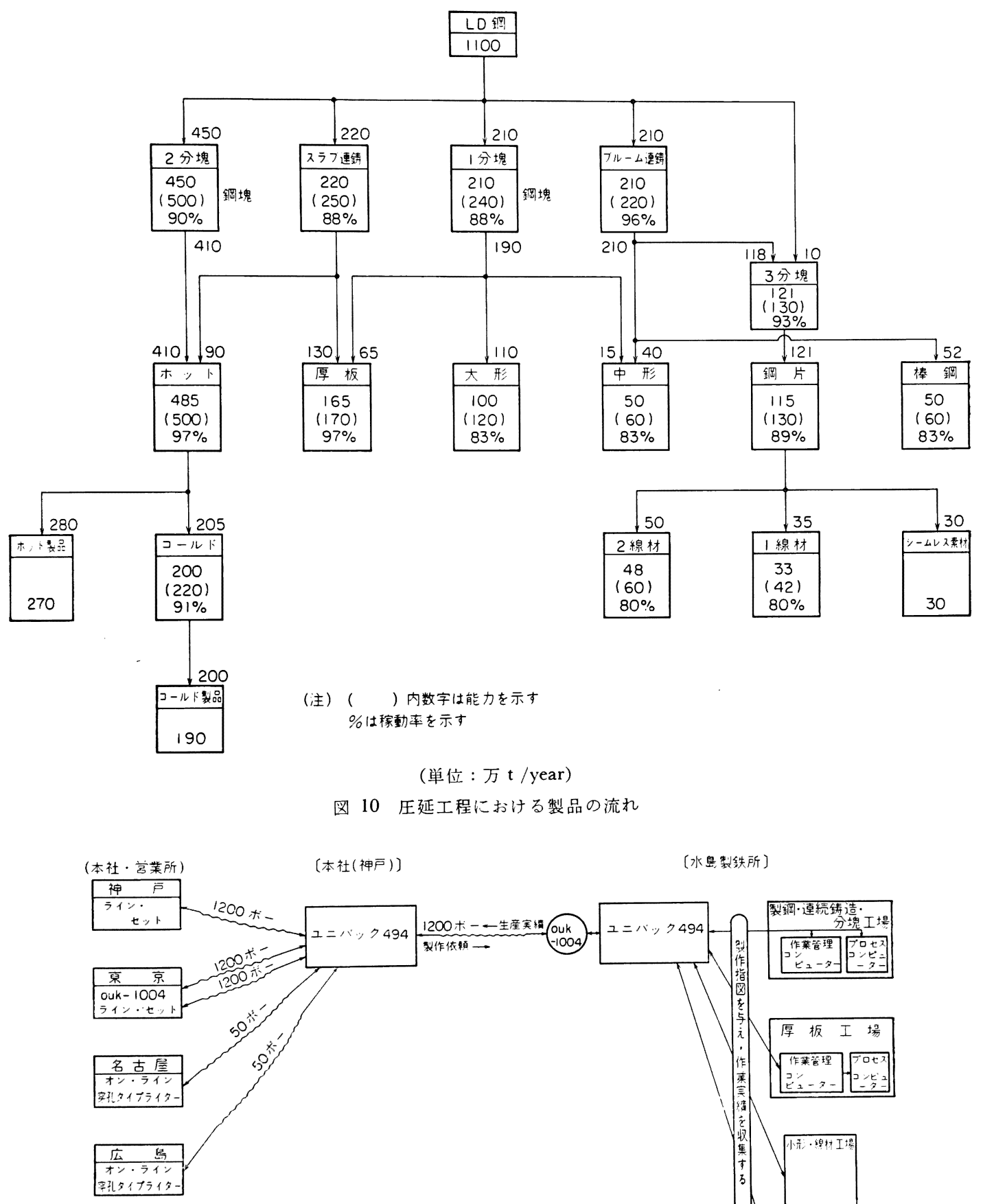

[水息慜铁所]

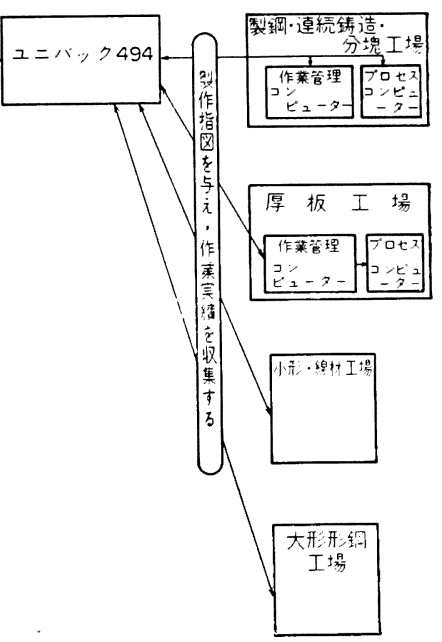

図 11 営業・工程情報システム網 
品に例をとれば, ラダーストックは仕上最大重量 $62 \mathrm{t}$, 軸類は $70 \mathrm{t}$ となり，20〜30万 $\mathrm{t}$ 級の大型船の部品を十 分卡かないうるばかりでなく, 今後さらに船舶が大型化 してもその霹要に対応できると判断している。

\section{9. コンピューターシステム}

1100 万 $\mathrm{t}$ プラントで真に効萆のよい生産を行なうた めには, そのマネージメントと管理に対して, 計りしれ ない量と質の情報が要求されるであろうから, 集中化さ れた管理組織が必須のものとなる。この組織は巨大なも のになるので, レスポンスは一層速くなければならな い.コンピューター組織はこの見地のみからも今後の経 営・管理組織の中枢となるべきもので，当所においても 算 1 期工事完成洔の未来図を画き, 着々と革新的なシス テムを椣成しつつある。

当所コンピューター組織の特徵としては

(1) 製鉄所中央に管理センターを設けて生産管理の 中枢としての機能を持たせ, 大型の中央コンピューター を設置し, 神戸本社中央コンピューターと高速通信回線 で直結し, 全社のオンライン営業情報システムと即時的 つながりでオーダーがはいつてくる.

(2) 所内の中央コンピューターは従来の事務用計算 （実績集計などの事後処理）から一歩進えで，生産管理の 核心的部分（生産スケジュール, 生産命令の自動化）を 主機能としている。

（3）中央コンピューターの作成した生産命令は, 各 生産工場のオペレーション・コントロール・システムに 与えられ，ここで更に品質・能率・コストなどを最適化 するためのキメの細かい作業指示をつくつて, 現品と同
期してリアルタイムでプロセス自動運転機器や末端のオ ペレーターに指示する.

（4）各ユニットプロセスに対しては，プロセス・コ ンピューターによるプロセス運転の最邀化のコントロー ルを行ない，その手足としてシーケンス制御・D D Cな どサブシステムの面にまで, 自動化のためのコンピュー ターを積極的に導入してきた.

すなわち当所のコンピューター組織は, 中央コンピュ 一ターを頂点とする階段システムで，生産管理情報は頂 点から末端へ，をた末端から中央へリアルタイムで集約 さ机，生産規模の増大や高速化による情報の洪水に押流 されることのないよう準備を進めてきた．これは一方で は生産設備の自動運転や情報伝達・処理の自動化によつ て， $\mathrm{t} /$ 人の飛躍的向上をもたらすものであり，他方こ れら管理機能のサブシステムの積重ねにより，ミドル . マネージメント・レベルに対する情報網が完備し, さら にこれら集約された生産管理情報を基盤として, 原価 · 財務・環境情報などを含めた経営モデルにより，政策決 定に即応できる経営情報システムにつながるものであ る.

当初における営業・工程情報システム網の現状を図11 に示す.

\section{0. 所内輸送について}

粗鋼年産 1100 万 $\mathrm{t}$ 時点の所内工場間の輸送経路は図 12に示すとおりである.

所内軌道は建設費の節減のため狭軌としたが，特に高 炉から製鋼工場に通ずる溶銑輸送用 $250 \mathrm{t}$ トーピドーの 軌道については，その基礎工事を入念にして事故の未然

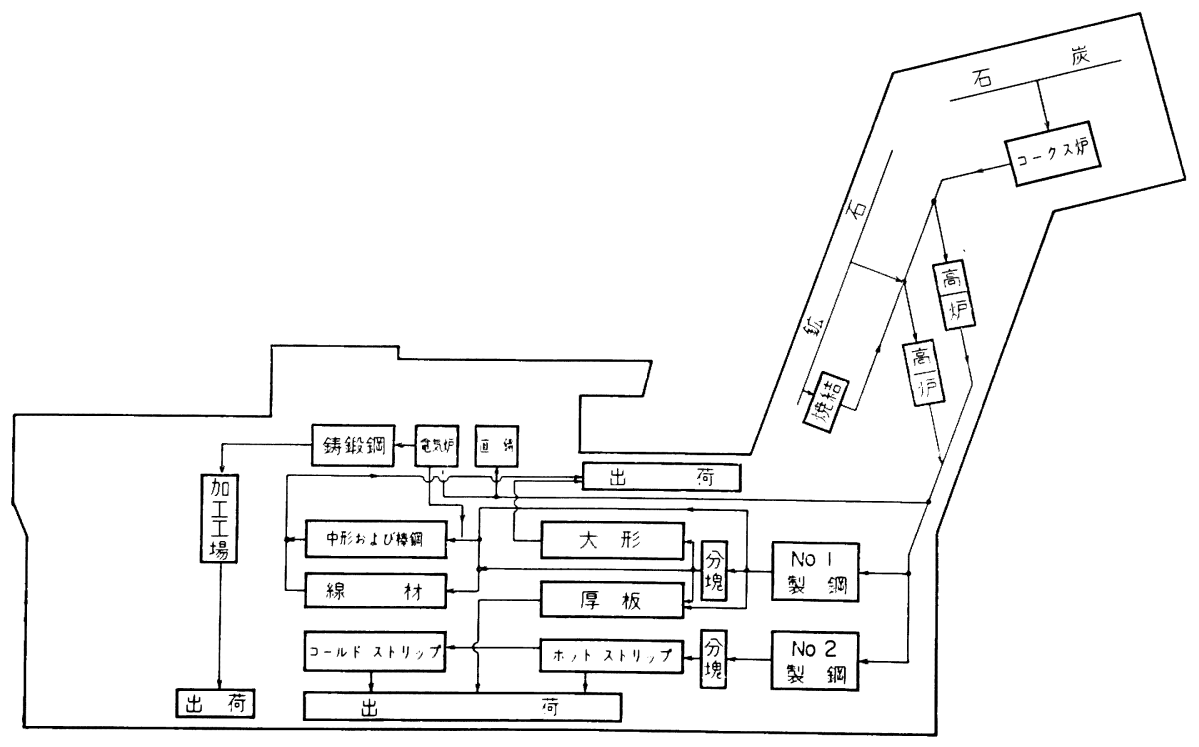

因 12 工場間輸送経 路図 
防止につとめた。

出鉄量は 1 日平均 $26000 \mathrm{t}$ 最高 $28500 \mathrm{t}$ となるが, 1 回の出鉄量を平均 $500 \mathrm{t}$ としても 1 日当たり出銑回数 は 52〜57 回となり，これに対して千葉こ採用している ような取鍋輸送方式では，溶銑列車の編成数が莫大とな つて時刻表を組むことが困難となるほか，製鋼工場での ちよつとした事故の場合にも，高炉一転炉間の線路が長 、溶鉄列車で詰まつてしまうおそれさえ生じか权ない。 これに対しトーピドーでは 1 回の出銑につき 3 台を配車 すればよく，その操作は比較的容易である。これがトー ピドーを採用したおもな原因である。

$2 つ の$ 転炉工場における生産品種を適当に配分するこ とにより，製鋼工場からの材料の流れは大きく 2 分され る.すなわちスラブを素材とする厚板および薄板は高梁 川岸壁へ，ブルームを素材とする形銅・棒銅掞上び線材 は切込港湾の製品岸壁へ送られ，両者間またそのおのお の経路について折返し, 交叉は全くない, 他方電気炉工 場経由の鋳鉎鋼品の出荷は高梁川上流に専用の積出し岸 壁を設置して，一貫体制の製品輸送とは舆関倸にしててあ る.

\section{1. 廃宩物の処理}

\section{1 . 1 高妒浫}

出銑量 $26000 \mathrm{t} /$ dayに対し約 $8000 \mathrm{t} /$ day の高忓 ス ラグが発生するが，これは各高炉周辺のドライピットで 冷却固化してのち，製鉄所北部地区に設置した鉱滓バラ ス工場へダンプまたはトラックで輸送し，ここで各種サ イズに破厒整粒する。製品は骨材線路道路用研石として 場内使用または外販する。 また発生する $0 〜 5 \mathrm{~mm} \mathrm{のサ}$ イズのものは,川鉄鉱業(株)の珪カル原料として売却す ろ.

\section{$11 \cdot 2$ 祘炉滘}

製鋼工場南側に畠を設けて冷却後，高炉滓と同様に破 砕整粒して埋立または売却にあてる。なお混入する地金 を回収するとともに，一部高炉原料として使用すること る考慮している。

\section{$11 \cdot 3$ ダスト}

高炉・焼結機および転炉から発生するダストは，おの おののシックナーにてスラリーとし，これを焼結工場の 近くに設置したダスト処理工場へパイプ輸送しここで 眖水・乾燥してセミペレットとし焼結原料に使用する.

\section{4 排気中の $\mathrm{SO}_{2}$}

水島地区は石油・化学・鉄鋼および電力の大コンビナ

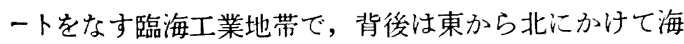
拔 $200 \mathrm{~m}$ くらいの丘陵に囲まれ，西は高梁川を越えて海 岸線に広がる平野部になつている.工業地帯の背後には 200 ha の農地, 山簏部には果樹園があり,これらに対 する $\mathrm{SO}_{2}$ の影響は無視できない.

当所第 1 期工事完了時の排出ガス中の $\mathrm{SO}_{2}$ 濃度は,さ
きに行なわれた通産省の総合事前調査によると $387 \mathrm{ppm}$ となつた．そこで副生ガスを最大限燃料として使用し， 重油の消費量を極力圧縮し, さらに低硫黄重油の使用を 考虑すれば，排ガス中の $\mathrm{SO}_{2}$ 浱度は $263 \mathrm{ppm}$ に下が るとの見通しがついた．そのうえ鋳錐鋼工場などの小能 力の炉が多いものは集合煙突, 焼結・熱延加熱炉など大 量の排ガスを排出する設借は高集合㖶突とすることによ つて, 排ガスの拡散改善が期待でき, 地域基準浱度 0.2 ppm に対する当社の改善目標値を下迴ることになり， この地域に対する公害の発生を未然に防止できるものと 思われる。

\section{2. エネルギーバランス}

\section{$12 \cdot 1$ 電力}

第 1 高炉の完成とあわせて所内に水島共同火力(株)が 設立され，高炉のBガスと重油を使つて発電しており， 最終的には $75 \mathrm{~kW} 2$ 基, $156 \mathrm{~kW} 2$ 基の合計 4 基の発電 機を備えることになる.

粗鋼 1100 万 $\mathrm{t}$ 時の電力バランスは, 製鉄所敷地の北 端に工場をもち，電力の大口需要家である水島合金(株) を含めて図 13 に示すとおりであつて, 総合年間所要電 力は 36.3 億 $\mathrm{kWh}$ となり, これに対し水島共同火力 (株)の発電量は年間約 32 億 $\mathrm{kWh}$ で, 残り不足分は中 国電力より買電することになる。しかし実际上圧延設備 特にホットストリップミルの負荷のピーク時とか, 各発 電機の定期検査または突発休転時に注, 相当量の電力を 中国電力より買電することになる。

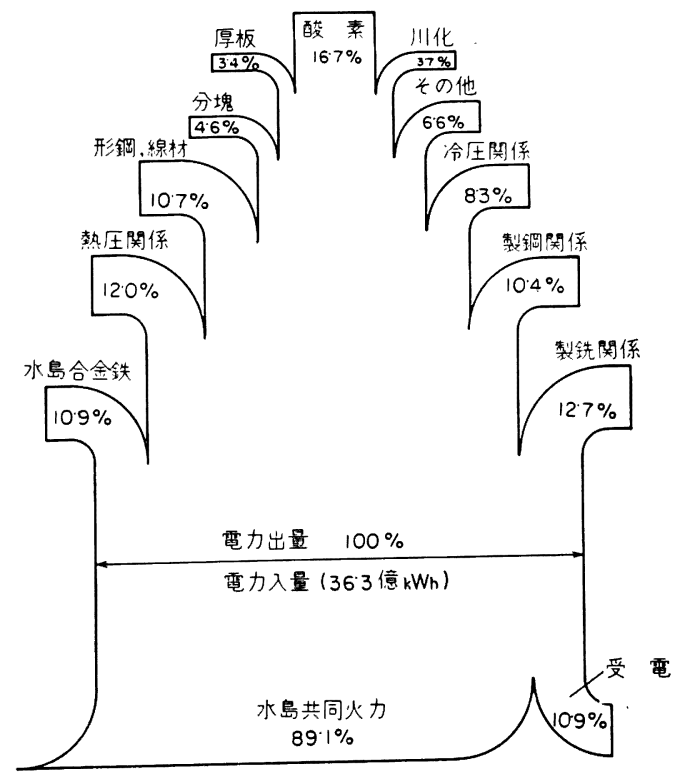

因 13 電力パランス 


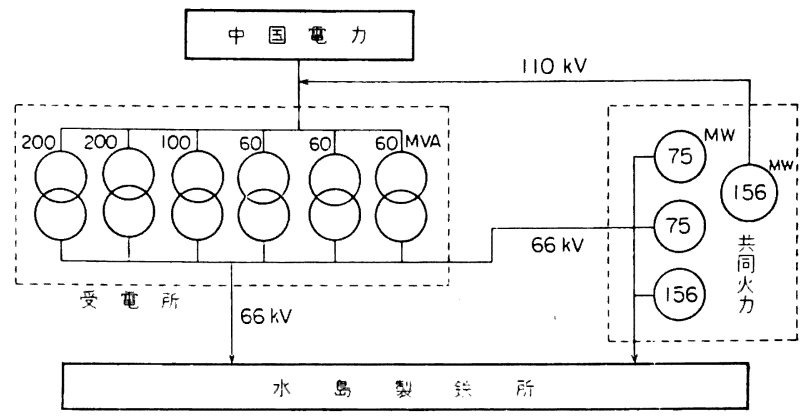

図 14 受配 電系 統図

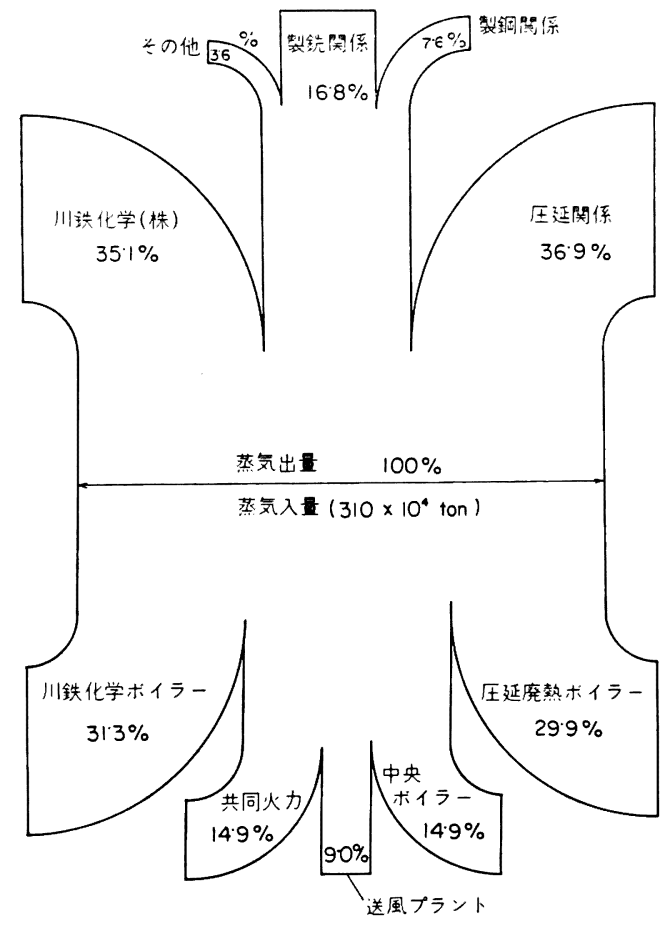

図 15 蒸気パランス

現在，所内の受電所には $60 \mathrm{MVA} \times 3$ 基および 100 $\mathrm{MVA} \times 1$ 基のトランスを持つが，将来さらに $200 \mathrm{MVA}$ 2 基を増設して上記の買電の事態に備える. 中国電力. 水島共同火力および受電所間の配置は図 14 のとおりで ある・

\section{$12 \cdot 2$ 蒸 気}

蒸気バランスは図 15 のとおりて，年間消費量は 310 万 $\mathrm{t}$ 上推定され，うち $1 / 3$ 以上が川鉄化学(株)が消費す る. 単位時間あたりのピークでは約 $660 \mathrm{t} / \mathrm{hr}$ となるが 各消費場所近くにボイラーを置いてこれをまかなうこと になる。

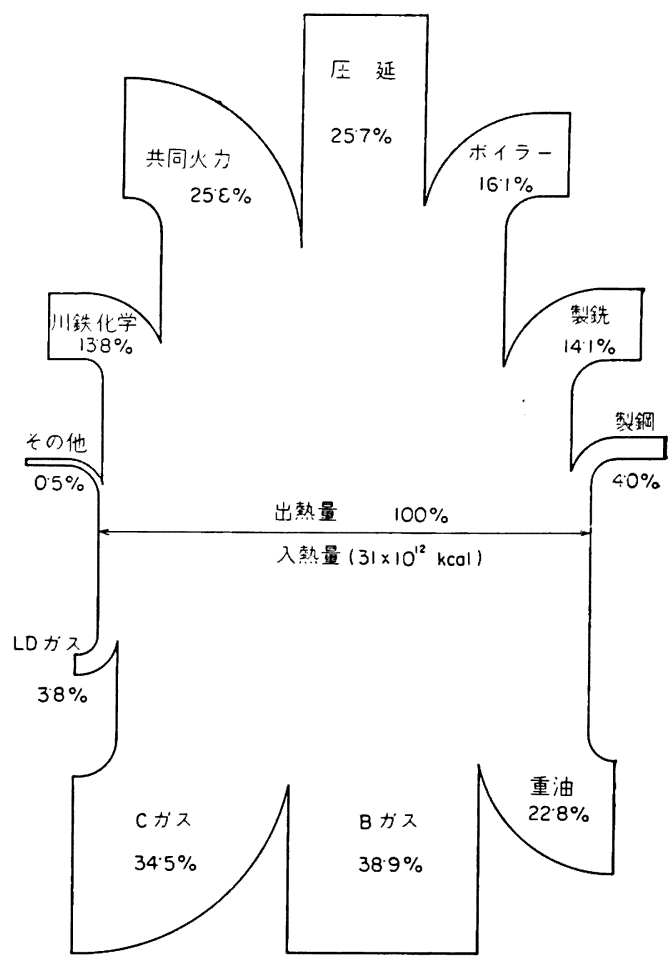

図 16 熱量バランス

\section{$12 \cdot 3$ 熱 量}

所内燃料は B.C および L D ガスと不足分を重油で 補う・第 1 期工事完了時のガス・ホールダーとしてはB ガス用は 20 万 $\mathrm{m}^{3} 1$ 基, $\mathrm{C}$ ガス用 7 万 $\mathrm{m}^{3} 2$ 基, $\mathrm{L} \mathrm{D}$ ガ ス用 5 万 $\mathrm{m}^{3} \cdot 8$ 万 $\mathrm{m}^{3}$ 各 1 基よりなる. 各ガスは単味ま たはミックス・ガスとして使用する. 重油タンクは製銑 地区に $8000 \mathrm{t}, 2500 \mathrm{t}$ 各 1 基, 压延地区に $5000 \mathrm{t}$, $2500 \mathrm{t}$ 各 1 基よりなりいずれも低硫黄重油を使用する ことになる。

熱量バランスは図 16 に示すが，年間綜合約 31 兆 $\mathrm{kcal}$ 推定される. 


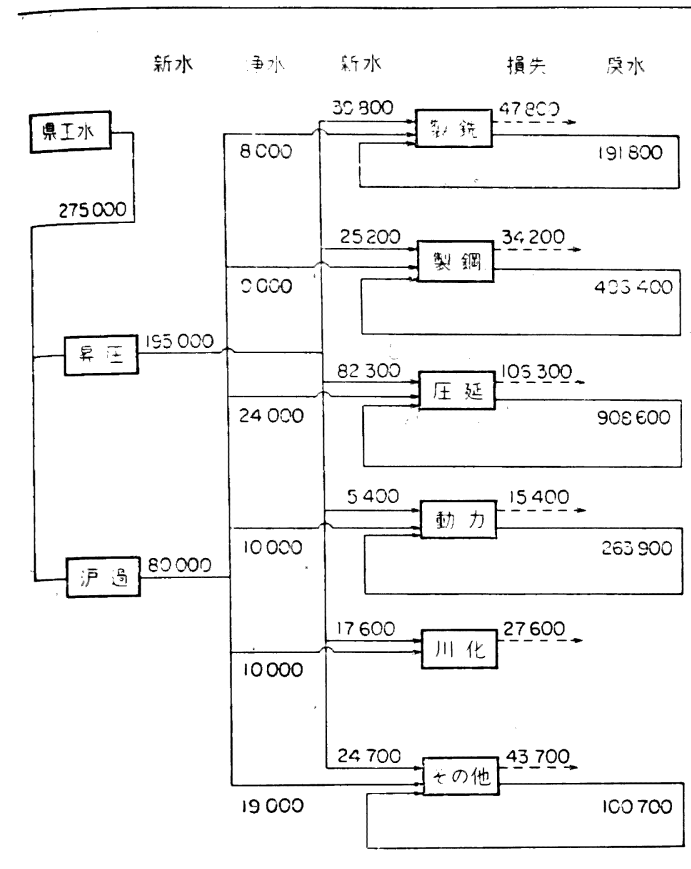

因 17 淡水使用内訳 （単位: $\mathrm{m}^{3} /$ day）

\section{4 工業用水およひ浄水}

粗銅 1100 万 $\mathrm{t}$ 時の淡水使用状況は図 17 のとおりで 全淡水用量は約 224 万 $\mathrm{m}^{3} / \mathrm{day}$ て原単位は約 $74 \mathrm{~m}^{3} / \mathrm{t}$ と

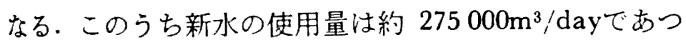

て，還水率は約 $88 \%$ となり，新水の原単位は約 $8.9 \mathrm{~m}^{3}$ / $\mathrm{t}$ 上六る. 浄水は所内 3 力所の浄水場で工業用水を浄 化して送水する.

所要工業用水の水源は，水量豊富な高梁川水系をひか 兑，岡山県工業用水の水島地区全体の長期計画が着々と 進奶られて打り, 将来 100 万 $\mathrm{m}^{3} / \mathrm{day}$ の取水が可能であ つて, 当所の必要量は十分確保できる見通しである.

\section{3. 総}

括

水島製鉄所怡昭和 36 年立地を決定して以来, 昭和 42 年春に第 1 高炉の完成により一貫体制を確立し,ついで 本年 1 月第 2 高师火入れ纪より年産粗鋼 450 万 $\mathrm{t}$ の規模 に拡大され，ひきつづき第 $3 \cdot 4$ 高炉を建設して昭和 47 〜 48年頃には, 大型高炉 4 基, 転炉 6 基・連続鋳造設 備・各種圧延設備および鋳鍛造設備を備えだ粗鋼年産 1100 万 $\mathrm{t}$ の世界最大級の臨海製鉄所となる見通しであ る.

本製鉄所の建設にあたつては，製鉄技術の粋をあつめ て大型化・自動化・スピード化をはかり, 他方地域社会 に及ぼす公害を最小限にくい止める諸施策をほどこして 真に緑と太陽に恵まれた理想的な「世界をめざす製鉄所」 へと完成を急いでいる．この製鉄所の完成により当社は 東の干葉製鉄所に対応寸る西の拠点として, 需要家の要 求に即応しうるばかりでなく，激化する国際競争に打ち 勝つて，国家経済に大いに貢献することになるう。 